\title{
The Veneration of the Owl in Græco-Roman Egypt
}

\author{
Sara El-Sayed Kitat \\ Associate Professor in the Tour Guiding Department, Faculty of Tourism and Hotels Alexandria University, \\ Egypt \\ "Corresponding Author: Sara El-Sayed Kitat, Associate Professor in the Tour Guiding Department, \\ Faculty of Tourism and Hotels Alexandria University, Egypt
}

\begin{abstract}
The owl was a symbol of sickness, evil, and death in ancient Egypt. The bird was used as a determinative for the word Hsq meaning to "decapitate". Mummified owls were discovered in the subterranean galleries at Tuna el-Gebel. Owls were named the "keen-sighted hunters," birds of mourning and death and being therefore connected with the sun god Re. By the Ptolemaic period, plaques bearing the shape of the owl might be functioned as ex-votos for a solar deity. Bronze statues were discovered representing an owl beside Harpokrates. Thus, the owl was assumed to be one of the sacred animals of Harpokrates as a lunar deity. The relation between the owl and Horus might be due to goddess Neith who was described to be the mother of Harpokrates. Neith was equated with the Greek Athena whose sacred bird was the Little Owl. Both Neith and Athena were patron deities of weaving and spinning. Loom-weights were sometimes decorated with the shape of the owl. This bird became a main motive on Neucratis coins, which were imitations of Athenain coins. The shape of the owl was found on the "sabakes" coins of Egypt, and Ptolemaic coins bearing the shape of Serapis and Isis.
\end{abstract}

Keywords: Owl, death, sun cult, Harpokrates, Neith, Athena

\section{INTRODUCTION}

Scholars identified different species of owls in ancient Egypt. According to Meinertzhaegn, eight species of owls were known in Egypt. ${ }^{1}$ On the other side, Loret and Gaillard listed six types according to the discovered mummified owls. ${ }^{2}$ Namely three species of the owls; the Barn Owl, the Eagle Owl, and the Little Owl were classified as resident birds in ancient Egypt. ${ }^{3}$ As for the Starited Scops Owl, it appeared as a winter migrant in Lower Egypt. ${ }^{4}$

The shape of the owl was used as a remarkable hieroglyphic sign in the ancient Egyptian language. ${ }^{5}$ Houlihan believes that the Eared Owl (Mabo bubo / Asio otus) ${ }^{6}$ is frequently found in the Hieroglyphic writings unlike the Barn Owl (Tyto alba) ${ }^{7}$ which is commonly used as a hieroglyphic sign. ${ }^{8}$ According to Griffith, the owl sign referred to various types of owls except the Long-eared

${ }^{1}$ Meinertzhagen 1930, 349-364; Newberry 1951, 72.

${ }^{2}$ D' Lortet and Gaillard 1905, 167-170; Newberry 1951, 72.

${ }^{3}$ Newberry 1951, 72; Von Den Driesch et al. 2005, 234.

${ }^{4}$ Kemp 1988, 115-124; Von Den Driesch et al. 2005, 225, 234, table 11.

${ }^{5}$ Griffith 1898, 20; Kaplony 1977, 39; Coyette 2015, 93.

${ }^{6}$ Houlihan 1996, 145; Kaplony 1977, 39; The Eagle Owl is characterized with its stubby body, big eyes, and the erected feathers at the top of the ears identifying the existence of two "ears" for this owl. There are two types of this owl; the Eagle Owl (Bubo babo) which is mainly found in North Africa, Middle East, Asia, and Europe in the winter season. The second type is the Long-eared Owl (Asio otus) and breeds in the north of Equatorial Africa, Middle East, Asia and Europe. Nowadays, the Eagle Owl is found in Egypt in the Delta, particularly ElFayoum, Kharga oasis, and the Red Sea Coast. As for the Long-eared Owl, it appears in modern Egypt as a winter immigrant in the Nile Delta; Houlihan 1988, 110.

${ }^{7}$ The specie is characterized with its large head, dark back wing as well as crown. As for the rest of the body, it is white in color. The heart-shaped face is also notable in the Barn Owl. This type of owls breeds in Europe in winter season, Africa, Middle East and Asia. In Egypt, Barn Owls are found in the oases of Dakhla and Kharga, in the Nile Delta, mainly in Fayoum and along the west coast of the Mediterranean Sea. The territories of the Seuz Canal are also places where Barn Owls are found; Houlihan 1988, 108.

${ }^{8}$ Kaplony 1977, 39; Houlihan 1988, 109-110; Vernus 2005, 361; Coyette 2015, 93. 
Owl which was not used in early hieroglyphics. Newberry confirms that hieroglyphic sign represented mainly the Eagle Owl since the Predynastic Period. ${ }^{9}$

By the third dynasty, the Barn Owl was most commonly used to write this $\operatorname{sign}{ }^{10}$ It was depicted with his ears drown on his brow as early as the first dynasty. ${ }^{11}$ On the other hand, Gardiner in the first edition Egyptian Grammar named the sign as the Eagle Owl (Bubo bubo ${ }^{12} /$ Bubo ascalaphus); a nomination that was changed in the second edition of the same reference to be just "owl". ${ }^{13}$

Cottevieille-Giraudet rather believes that the Small Owl was the main representation for the sign but never attested before the $26^{\text {th }}$ dynasty ${ }^{14}$. The rounded-head Small Owl appeared in the texts from the Saite and Ptolemaic era. The Eagle Owl, the Barn Owl, as well as the Small Owl were textually represented in profile with a full headed face. ${ }^{15}$ In Hieratic texts, the Eagle Owl is written as $C_{\mathbf{L}}$ and

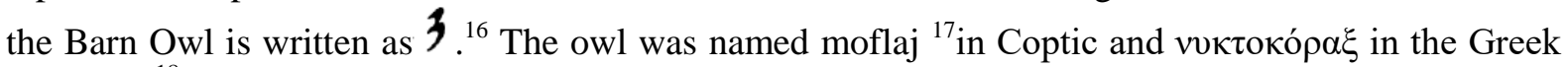
Language $^{18}$

\section{THE OWL; SIGN OF EVIL AND DEATH}

The owl was seemed to be a symbol of evil in ancient Egypt. In the Pyramid Texts, the bird was used as a determinative for the word HSQ 8 l $\triangle$ which means to "decapitate". The same meaning was represented as an owl chopped of by a knife ${ }^{3} .19$ This verb was also mentioned having the same meaning in certain Ptolemaic texts. ${ }^{20}$ The discovery of decapitated mummified owls might confirm this fact. ${ }^{21}$ Thus, Griffith believed that the owl was regarded an omen for sickness and should be therefore beheaded. ${ }^{22}$

By the late period, the owl was considered to be a bird of death. ${ }^{23}$ The association of the owl with death depends on the word MWT ${ }^{24}$ which means "death". ${ }^{25}$ The word NTY IM

II means also "the realm of death". ${ }^{26}$ The sign of the owl was used also to form the word

\footnotetext{
${ }^{9}$ Griffith 1898, 20; Newberry 1951, 72; Houlihan 1996, 145; Vernus 2005, 361.

${ }^{10}$ Griffith 1898, 20; Newberry 1951, 72; Houlihan 1996, 145; The Barn Owl was depicted with his ears drown on his brow as early as the first dynasty; Houlihan 1988, 109-111; Vernus 2005, 361.

${ }^{11}$ Houlihan 1988, 109-111.

${ }^{12}$ Houliahn 1996, 145.

${ }^{13}$ Gardiner 1927, 460; Gardiner 1950, 464; Newberry 1951, 72; Coyette 2015, 93.

${ }^{14}$ Newberry 1951, 72; see; Cottevieille-Giraudet 1931.

${ }^{15}$ Newberry 1951, 72; Coyette 2015, 93-94.

${ }^{16}$ Newberry 1951, 72-73; Coyette 2015, 94-97, fig.6.

${ }^{17}$ Griffith 1898, 20; Newberry 1951, 73.

${ }^{18}$ Griffith 1898, 20; Newberry 1951, 73; various species of owls were recognized with many Greek names. For instance, the Horned or the Long-eared Owl (strix otus) was named AI'ГОКЕ'ФА $\Lambda$ O $\Sigma$ and NYKTIKO'PA. The words $\mathrm{AI}^{\prime} \Gamma \Omega^{\prime} \Lambda \mathrm{I} \Sigma$, KIKKA'BH, KOKKOBA'PH were used to refer to the owl in general. The Bran Owl (strix flammea) was named as $\mathrm{AI} \Omega \Lambda \mathrm{IO} \Sigma$. As for the Eagle Owl (strix bubo), it was named BY'A $\Sigma$ and probably 'YBPI' $\Sigma$. The Short-eared Owl was assumed to be named 'E $\Lambda E O ' \Sigma$. The Little Horned Owl or the Scops Owl was named $\Sigma \mathrm{K} \Omega \Psi$. The Horned Owl particularly the Short-eared owl was name ' $\Omega \mathrm{TO} \Sigma$; Thompson 1936, 15-17, 40-41, 53, 82, 87, 119-120, 174, 200-201.

${ }^{19}$ Griffith 1898, 20; Erman and Grapow 1971 III, 168, no.15, 16, 17; Malaise 1993, 154; Coyette 2015, 100101.

${ }^{20}$ Erman and Grapow 1971 III, 168, no.15, 16,17; 169, no.1; Malaise1993, 154.

${ }^{21}$ Malaise1993, 154.

${ }^{22}$ Griffith 1898, 20; Malaise 1993, 154; the word HSQ 8 أ was also translated to be "disease"; Erman and Grapow 1971 III, 169, no. 5.

${ }^{23}$ Brugsch 1868, 21; Keller 1913, 42; Erman and Grapow 1971 II, 218, no. 18; Kaplony 1977, 39-40; Arnold 1995, 47, no. 55; Vernus 2005, 361; Coyette 2015, 101.

${ }^{24}$ Erman and Grapow 1971 II, 55, no. 9

${ }^{25}$ Erman and Grapow 1971 II, 218; Kaplony 1977, 39-40; Coyette 2015, 101.

${ }^{26}$ Erman and Grapow 1971 I, 72, no. 6.
} 
IM relation between the owl and the death is due to being one of the nocturnal birds just like the bats. ${ }^{28}$ This function of the owl was found in other cultures. In the Roman civilization the owl was described to be the bird of mourning and death. This was apparently because owls were sometimes found inside the tombs. According to its fearful appearance, fury looking eyes, and its remarkable moan, the owl was believed a bad omen in the Roman world. ${ }^{29}$

During the fifth century A.D., the Egyptian philosopher Horapollo linked between this bird and the concept of death. In Horapollo II.25, the night owl "signifies death, for it suddenly pounces upon the young of the crows by night, as death suddenly overtakes men". ${ }^{30}$ Furthermore, Owl-shaped amulets were discovered in the tombs of the Pharaohs confirming its protective function. Being connected to the death, these amulets were apparently used to protect its wearer from the dangers that he might face after death. Examples of these talismans were excavated in the tomb of Amenhotep II in the Valley of the Kings (KV 22) in 1915. One of these amulets is made of fiancé and is now preserved in the Metropolitan Museum of Art (fig.1). ${ }^{31}$

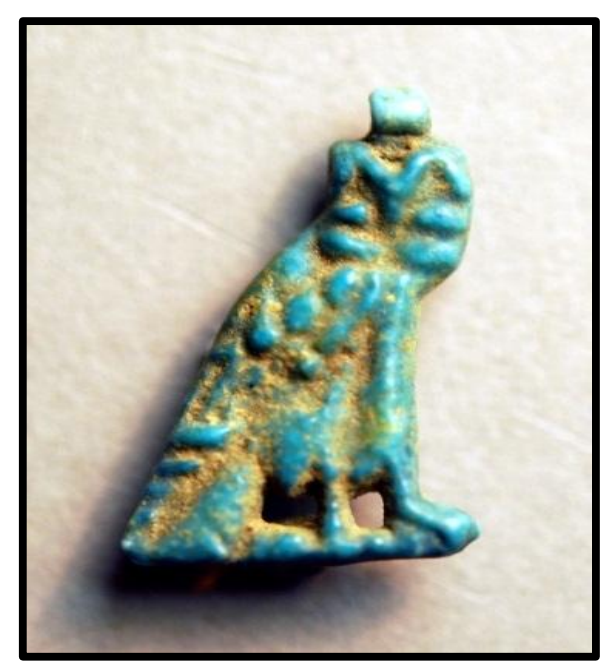

Fig1: Owl-shaped amulet made of fiancé and discovered in the tomb of Amenhotep III (KV 22), Valley of the Kings, Thebes, Metropolitan Museum of Art, New York

After: The Official Web Site of the Metropolitan Museum of Art (Accession Number: 26.7.1082)

https://images.metmuseum.org/CRDImages/eg/original/26.7.1082_front.nk.jpg

\section{MUMMified OWLS; DisCOVERY AND FunCTION}

It seems that the owl was in a way or another venerated in ancient Egypt. The discovery of mummified owl confirms this hypothesis. The old but secondary symbol of the beheaded evil owl recalls the im aspect and was known in Upper Egypt as one of the harmless fauna. ${ }^{32}$ In the predynastic HK29A fauna of Hierakonpolis, remains of owls were discovered together with other traces of falcons and eagles. ${ }^{33}$

The earliest discovered species are three mummified owls were discovered in Thebes. Pettigrew threw the light on these species which reached the hands of Passalacqua. One of them was discovered with

${ }^{27}$ Erman and Grapow 1971 I, 77, nos. 12, 13; Kaplony 1977, 39.

${ }^{28}$ In the hymns of Amun, death was equated with sleeping at night; Coyette 2015, 101.

${ }^{29}$ Witches were described wandering on earth just like owls. In the writings of Apuleius, a witch from Thessaly was turned into an owl; Keller 1913, 37.

${ }^{30}$ Cory 1840, 103-104; Kaplony 1977, 39-40; Coyette 2015, 101; In Horapollo II. 92, the owl was regarded an augury of a plentiful vintage. It was believed that if the owl sings or moans before the harvest season, this would be an omen of good vines; Cory 1840, 142.

${ }^{31}$ The Official Web Site of the Metropolitan Museum of Art (Accession Number: 26.7.1082)_https://images. metmuseum.org/CRDImages/eg/original/26.7.1082_front.nk.jpg

${ }^{32}$ The head of the owl decorated the knife was described to be "the mourning house"; Kaplony 1966, 65-70; Kaplony 1977, 39- 40.

${ }^{33}$ Gautier 1987, 47-52; Linseele et al. 2009, 111-112, table2. 
short but heavy feathered head. Therefore, M. Savigny who was the first one who described this specie named it after the Greek guardian of Hades' fields Ascalaphus (fig.2). ${ }^{34}$

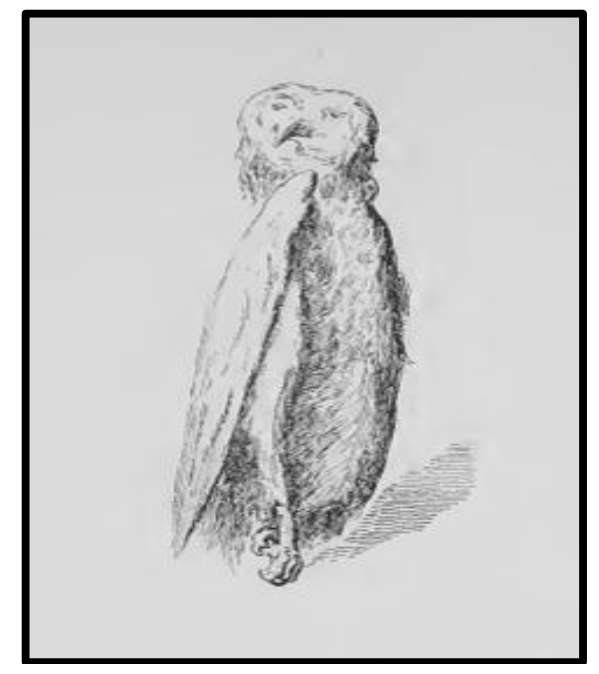

Fig2: One of the three mummified owls obtained by Passalaqua from Thebes

After: Pettigrew 1834, pl. XIII, fig.3

Different types of mummified owls were discovered in the subterranean animal necropolis at Tuna elGebel (galleries D, C, and B) ${ }^{35}$. These galleries date back to the Persian Period and continued till the Ptolemaic era ${ }^{36}$. Five Barn Owls (Tyto alba), six Eagle Owls (Bubo bubo), seventeen Short-eared Owls (Asio flammeus), fifteen Little Owls (Athene noctua), and only one Scops Owl / Striated Scops Owl (Otus scops / Otus brucei) were discovered in this area ${ }^{37}$. A solemn owl bone was discovered in the Gallery B-E. This part belongs either a Scops Owl (Orus scops) or the rare type of Straited Scops Owl (Otus brucei). The first type appeared only as a visitor in the western desert of Egypt. ${ }^{38}$

The Eagle Owl lived in the mountain of Tuna El-Gebel and was remarked with its small size, unique voice, and different markings from the other types of owls. Thus, Kemp rather regarded the Eagle Owl, which originally came from North Africa, a remarkable sort of owls ${ }^{39}$. Concerning the Little Owl and the medium-sized Short-eared Owl, they formed together the most common species found in the galleries of Tuna El-Gebel. The area of Tuna El-Gebel presented the suitable environment for breeding the Short-eared Owl which lived in hillsides, deserts, and marshes ${ }^{40}$.

Salima Ikram identified four main types of mummified animals. The first type is victual mummies presented as food offerings after death. Some animals were rather the favorable pets for their owners who preferred to be accompanied by their pets after death. The third type of mummified animal functioned as a sacred animal for a certain deity worshipped during its lifetime and mummified after its death. It could also be presented as a votive mummy presented at the shrines of certain gods. ${ }^{41}$ Since owls could not be sorted under the first two categories, mummified owls were rather sacred birds of certain deities or votive species for these gods. However, the lack of any archaeological evidence hinders identifying to which deity was the mummified owl dedicated to.

\footnotetext{
${ }^{34}$ Pettigrew 1834, 204; According to the Metamorphosis, Ascalaphus, the guardian of Hades' orchard, told the gods that Persephone ate from the seeds of the Pomegranates form the Underworld. Thus, Persephone was punished by being obliged to spend four months, or six months in other versions, there. Demeter, mother of Persephone, or Persephone herself in return turned Ascalaphus into an owl, mainly an eagle owl ('A $\Sigma \mathrm{KA} \Lambda \mathrm{A} Ф О \Sigma$ ); "He has now become a lazy screech owl that hated bird, which brings news of approaching grief for mortal men, a fateful omen. Now Ascalaphus would seem to have deserved his punishment by telling what he": Keller 1913, 38; Thompson 1936, 36; Ovidius, Metamorphoses, Book V, 533-371.

${ }_{35}$ Kaplony 1977, 39; Kessler and Nur el-Din 2005, 154-156; Von Den Driesch et al. 2005, 217, table 2.

${ }^{36}$ Kessler and Nur el-Din 2005, 144-157; Von Den Driesch et al. 2005, 205-206.

${ }^{37}$ Von Den Driesch et al. 2005, 217, table 2.

${ }^{38}$ Kemp 1988, 115-124; Von Den Driesch et al. 2005, 225, 234, table 11.

${ }^{39}$ Kemp 1988, 122; Von Den Driesch et al. 2005, 234.

${ }^{40}$ Von Den Driesch et al. 2005, 234.

${ }^{41}$ Ikram 2004, 6.
} 
Mummified owls in this area were certainly turned to gods. Like other mummified animals, owls were ritually devoted as offerings to certain deities. After being relentlessly killed, throttled, beheaded, or even burnt, the bird was mummified and deified. Thus, its sacred body was preserved in its elaborate container. By the Ptolemaic period, thousands of birds from different breeding sites were yearly mummified and presented in Hermopolis as votives. ${ }^{42}$

\section{THE OWL AND THE SUN CULT IN ANCIENT EGYPT}

Certain scholars related the owl with the sun god Re. ${ }^{43}$ the eyes of the owls were said to be inlaid with the sun eyes. ${ }^{44}$ The sign of the owl was used also to form the word mA "to see". ${ }^{45}$ Thus, owls were named the NW ${ }^{2} \mathrm{O}$, I I I was known in Egypt as early as the $18^{\text {th }}$ dynasty. ${ }^{47}$

Owls in general, the Barn owl (Tyto alba) in particular, were represented in rare painting and sculpture works in ancient Egyptian art. ${ }^{48}$ By the Ptolemaic period, the shape of the Barn Owls was used as an independent sculpture model on some discovered plaques. ${ }^{49}$ The owl is depicted here en face as an exceptionally detailed figure with its remarkable heart-shaped flattened face. Having no ears neither hind toes, barn owls are depicted in art without them. ${ }^{50}$ The function of these plaques is still a topic of debate. Group of scholars including Houlihan believes that these plaques were sculptured by chief artisans or even by trainees to improve their skills. Some surviving examples were certainly carved by professional sculpture. ${ }^{51}$ On the other hand, this sort of plaques might be functioned as ex-votos for certain deities. Following this hypothesis, Arnold believes that owl-carved pieces were certainly dedicated to a solar deity. This is because of considering owls, "the keen-sighted hunters", birds of mourning and death. ${ }^{52}$ An example of these plaques is a limestone piece discovered by Rogers Fund in 1907 and preserved now in the Metropolitan Museum of Art (fig.3). This plaque dates back to the Ptolemaic period (304-30 B.C) and belongs to the same group of pieces revealing the shapes of a vulture and a cobra. ${ }^{53}$

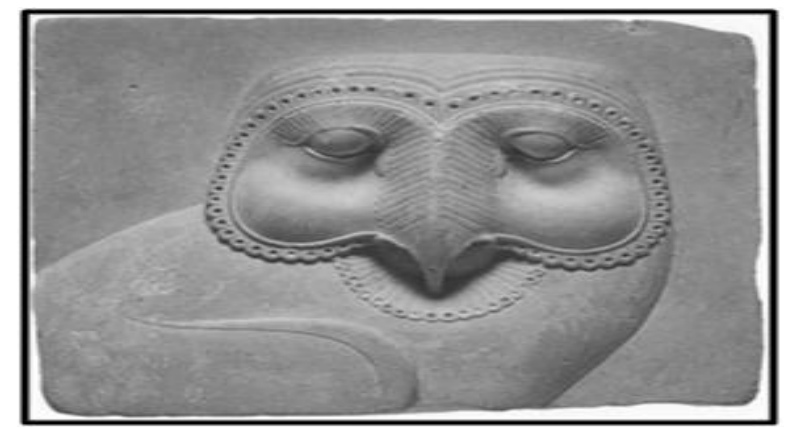

Fig3: Limestone piece revealing the head of the Barn Owl, Ptolemaic Period (304-30 B.C.), discovered by Rogers Fund in 1907, preserved in the Metropolitan Museum of Art

After: Arnold 1995, 47 no. 55

${ }^{42}$ Kessler and Nur el-Din 2005, 155-156.

${ }^{43}$ Keller 1913, 39-40; Malaise1993, 154-155.

${ }^{44}$ Kaplony 1977, 39-40; Arnold 1995, 47, no. 55.

${ }^{45}$ Kaplony 1977, 39.

${ }^{46}$ Erman and Grapow 1971 II, 218, no. 18; Kaplony 1977, 39-40; Arnold 1995, 47, no. 55.

${ }^{47}$ Kaplony 1977, 39-40.

${ }^{48}$ Arnold 1995, 47, no. 55; Coyette 2015, 98-100; For instance, a carved scene shows the Barn Owl in the Temple of Deir El Bahari. Another painted scene shows this specie in the eighteenth dynasty tomb of Neferhotpe (TTA5-E 13101) at Thebes. It is depicted exceptionally in profile with its rounded head and white heart-shaped face among the marshes of papyri. Furthermore, the owl was depicted on the walls of the Theban tomb of Ipuy (TT 217) perching on a papyrus stem in front of the boat that carries Ipuy and his family. Despite the lack of colors, this specie was identified to be a Barn Owl. Traces of another Barn Owl are found in a fishing scene in the tomb of Suemnut at Thebes (TT 920); Houliahn, 1996, 145; Houlihan 1988, 109-110, figs. 156-158; Coyette 2015, 98-100, fig.7.

${ }^{49}$ Houlihan 1988, 109-110, figs. 156-158; Arnold 1995, 47, no. 55; Coyette 2015,102.

${ }^{50}$ Houlihan 1988, 109-110, figs. 156-158; Arnold 1995, 47, no. 55; Coyette 2015, 98-100.

${ }^{51}$ Houlihan 1988, 109-110, figs. 156-158; Arnold 1995, 47, no. 55.

${ }^{52}$ Arnold 1995, 47, no. 55.

${ }^{53}$ Arnold 1995, 45-46, nos.51-52; 47, no. 55. 


\section{THE OWL, THE FALCON AND GOD HORUS}

Bronze statues were discovered in which the owl is represented beside Harpokrates. This led some scholars to assume that the owl was one of the sacred animals of god Horus. ${ }^{54}$ Examples of these statues depict the deity flanked by the owl on the right side and the dog on the left side. The owl is depicted wearing the kalathos of god Serapis. As for Harpokrates, he is depicted as a winged youth holding the cornucopia in his right hand. A snake is depicted being twisted along a long rod beneath the cornucopia. In other statues, another owl is depicted perching on the left arm of Harpokrates (figs. $4 \mathrm{a}, 4 \mathrm{~b}) .{ }^{55}$

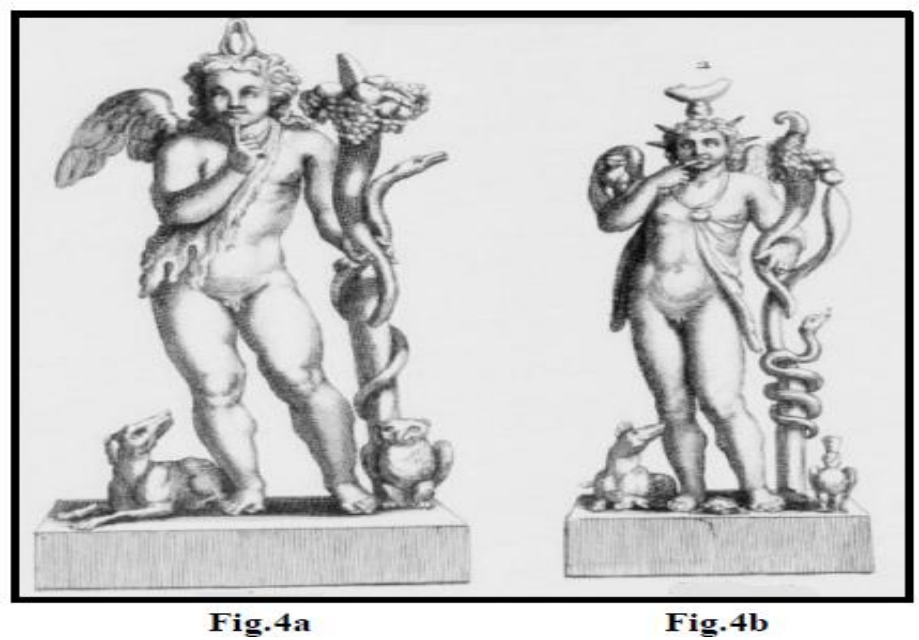

Figs4a, 4b: Statues representing Harpokrates accompanied with one owl (fig.4a) and two owls (fig.4b) After: De Montfaucon 1722, 302, pl. CXXIV

A remarkable example is a bronze statuette of Harpokrates that is now preserved in The Department of Coins, Medals and Antiques, Bibliothèque nationale de France (BnF) (inv.52.6557) (fig. 5). This piece depicts the deity a naked standing child. He is represented winged and crowed with the pschent. The index finger of his right hand is placed on his lips, his left hand holds a cornucopia. On the left shoulder, he wears a nebrid and steps his left leg forward. The left forearm is leaning on a tree trunk around which a snake twist. The trunk is provided with ring, placed horizontally between the wings. The whole statuette is placed on a small rectangular base. On the right side of the base, a perching a dog is found and on the left side, at the foot of the tree, an owl is depicted. ${ }^{56}$

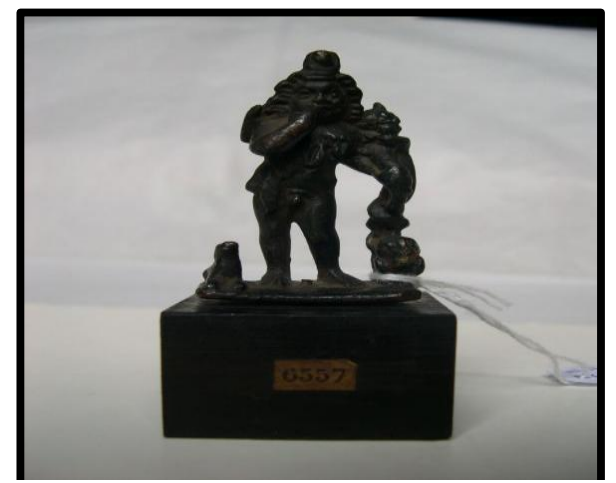

Fig5: Roman bronze Statuette of Harpokrates made of bronze. The owl is depicted on the right of the deity beneath the tree trunk, reign of Trajan, The Department of Coins, Medals and Antiques, Bibliothèque nationale de France (BnF) (inv.52.6557)

The Official Web Site of the Bibliothèque nationale de France (BnF) (inv.52.6557) http://medaillesetantiques. bnf.fr/ws/catalogue/app/collection/record/ark:/12148/c33gbfppk?fbclid=IwAR3sF8qUymWJkQmuXbmBujB_N5NaXw79AZ2nlyc_G5OkVplC8PV7Is4nB4

\footnotetext{
${ }^{54}$ De Montfaucon 1722, 302, pl. CXXIV, 454; Malaise1993, 153-154.

${ }_{55}^{5}$ De Montfaucon 1722, 302, pl. CXXIV.

56 The Official Web Site of the Bibliothèque nationale de France (BnF) (inv.52.6557) http://medailleset antiques.bnf.fr/ws/catalogue/app/collection/record/ark:/12148/c33gbfppk?fbclid=IwAR3sF8qUymWJkQmuXb mB-ujB_N5NaXw79AZ2nlyc_G5OkVplC8PV7Is4nB4
} 
The iconography of Harpokrates with the owl seems to be mysterious. Following the hypothesis of Malaise, such statuettes reveal the function of Harpokrets as a lunar deity rather than his solar cult. ${ }^{57}$ On the other hand, De Montfaucon rather believed that the statues that combine Harpokrates with the owl reflect the function of this deity as a solar god. ${ }^{58}$ Following this opinion, such statues would express the intermingling between two natural powers of the universe; namely the sun and the moon.

The function of the owl as bird of death is emphasized through these statutes. The owl is depicted flanking Harpokrates on one side and the dog, or apparently the jackal, ${ }^{59}$ is depicted on the other side. The association between the owl and the jackal in such statues confirm the function of the owl as the bird of death. The role of the owl as the bird of death is pictorially represented in the scene of weighting the heart of the deceased. This remarkable scene is found on a Ramesside ostracon discovered in Thebes. This piece which preserved now in the Museum of Art and Archaeology of Missouri, depicts a hippopotamus wearing the lion skin and facing a flying black crow. The animal is represented standing upright on its back legs over an object which might be the balance. Beneath the balance, the owl is depicted on the left side and a cat of the right side (fig.6). ${ }^{60}$ Despite of the absence of the owl's shape in any Pharaonic religious rites, the shape of owl might have replaced that of the falcon in the scene of weighing the heart. ${ }^{61}$ Thus, the owl might be used as one of the sacred birds of god Horus in general and Harpokrates ${ }^{62}$ in particular. However, its association with Horus did not spread widely unlike the falcon.

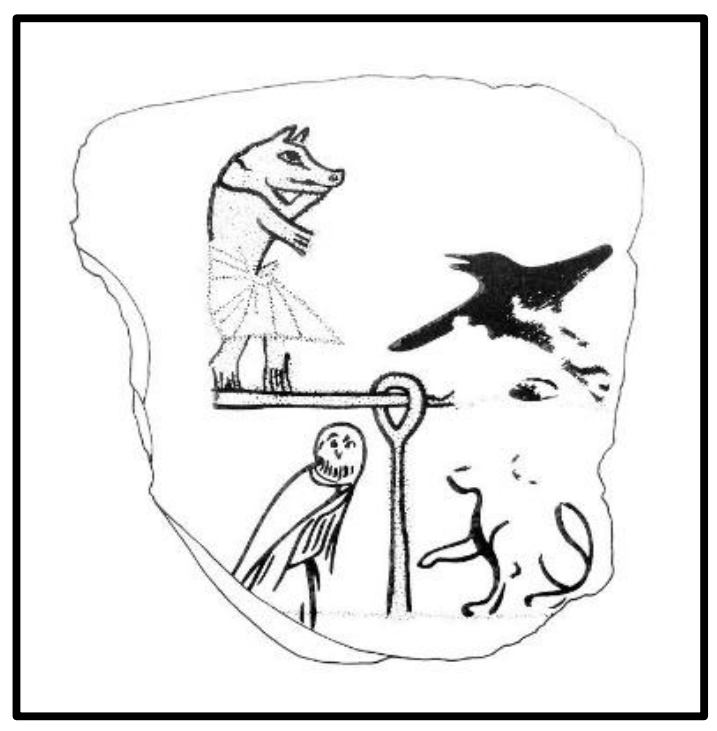

Fig6: Ostracon depicting an owl among the scene of weighing the heart of the deceased, Ramesside period, discovered in Thebes, preserved in the Courtesy of the Museum of Art and Archaeology, University of Missouri, Columbia

After: Houlihan 1988, 134, fig. 191

Being the sacred bird of Harpokrates, the owl which was believed to have an apotropaic power to ward off evil spirits, was used here for protection. Furthermore, Harpokrates might have been turned into an owl. This is due to the Roman traditions in depicting the falcon, the sacred bird of Horus, as an owl. ${ }^{63}$

The relation between the owl and god Horus might be due to goddess Neith who was equated with the Greek goddess Athena whose sacred bird was the owl. On the other hand, Neith was described in certain texts to be the mother of Harpokrates. ${ }^{64}$ However, Malaise refused the relation between the

${ }^{57}$ De Montfaucon 1722, 304, 454; Malaise 1993, 155.

${ }^{58}$ De Montfaucon 1722, 304.

${ }^{59}$ For the jackal god Anubis see; Wilkinson 2005, 187-190.

${ }^{60}$ Houlihan 1988, 134, fig. 191; Coyette 2015,100,

${ }^{61}$ Malaise1993, 155, n. 51; Coyette 2015,100.

${ }^{62}$ Keller 1913, 39-40; Malaise1993, 153-154; Coyette 2015, 102.

${ }^{63}$ According to Malaise, birds which were identified by Stricker as owls were mainly falcons; Stricker 1957, 114; Malaise 1993, 153-154; Coyette 2015, 102-103.

${ }^{64}$ Horus was described to suckle from his mother Neith, see; El-Sayed 1982 I, 111-114; Malaise 1993, 155. 
owl and goddess Neith since she was related with Horus in his fusion as a falcon not as an owl. The Egyptian goddess was named "the one who gave birth to the falcon". ${ }^{65}$ In the Greek culture, the eyes of the owl were described to be both frightening and protecting. Thus, Malaise rather believed that the relation between the owl and Harpokrates evokes the wakefulness and the prophylactic powers of Horus son of Isis. ${ }^{66}$

Being connected to god Horus, ${ }^{67}$ the owl might be relevant to kingship in ancient Egypt. In the temple of Semna, there is a striking scene that represents king Tuthmosis III performing a ritual race in front of goddess Hathour. The king is depicted holding three scepters in his right hand. The three scepters, the anx, Dd and wAs are surmounted respectively with three sacred birds; namely the ibis, the vulture and the owl (fig.7). ${ }^{68}$

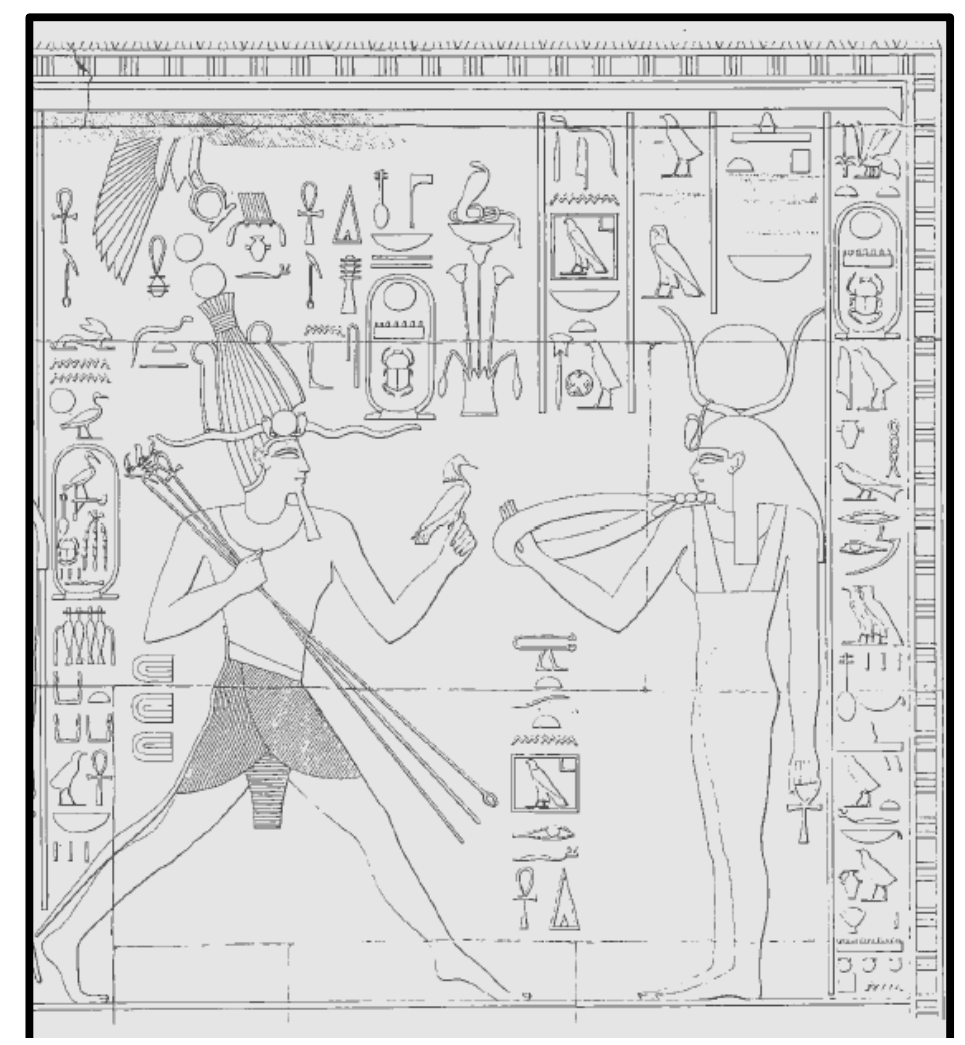

Fig7: Tuthmosis III in the presence of Hathour holding three scepters surmounted by three birds; the ibis, the vulture and the owl, temple of Khnum in Semna, room 4, west wall

After: Keel 1977, 126, fig.40.

\section{THE OWL, GODDESS NEITH AND GODDESS ATHENA}

In Predynastic times, A city named "Eagle-Owl City" was mentioned on a schist palette in Egyptian Museum (no. 14238) ${ }^{69}$ and was discovered in Abydos. ${ }^{70}$ A fortress called "Eagle-Owl City" was recorded among seven predynastic fortresses that had been destroyed by the governors of Upper and middle Egypt. ${ }^{71}$ Almost four of these cities were located in the western region of the Delta. ${ }^{72}$ The socalled Owl City is the largest depicted one and was attacked by the Falcon governor. ${ }^{73}$ In the so-called Libyan palette, an owl is depicted with the shapes of eight buildings surrounded with an enclosure

${ }^{65}$ El-Sayed 1982 I, 111-113; Malaise 1993, 155.

${ }^{66}$ Malaise 1993, 155.

${ }^{67}$ For Horus as god of kingship see; Meek 1977, 1006; Wilkinson 2005, 201.

${ }^{68}$ Keel 1977, 125-126, fig. 40; Malaise 1993, 154.

${ }^{69}$ Newberry 1951, 73; Saleh and Sourouzian 1987, 7, pl.7a,7b; Houlihan 1988, 110-111; Coyette 2015, 93.

${ }^{70}$ Saleh and Sourouzian 1987, 7, pls.7a,7b.

${ }^{71}$ Legge 1900, 134-135, pl.5; Newberry 1951, 73-74; Houlihan 1988, 110-111; Coyette 2015, 93.

${ }^{72}$ This is according to the depiction of olive trees and the captured Tehenu land on the reverse of this palette; Legge 1900, 134-135, pl.5; Newberry 1951, 73-74; Saleh and Sourouzian 1987, 7, pl.7a,7b; Houlihan 1988, 110-111.

${ }^{73}$ Legge 1900, 134-135, pl.5; Newberry 1951, 73-74; Houlihan 1988, 110-111. 
wall; a shape that symbolizes one of the Libyan cities. The figure of the owl identified the name of the city. The city is depicted attacked by a falcon is represented perching on the wall of the city and breaking its wall with a hoe. The owl is depicted here with full rounded face, large eyes, and erected ears. Thus, many scholars identified the depicted owl here as the "Eagle Owl". Houlihan rather believes that this bird might be an Eagle Owl or a Long-eared Owl (fig.8). ${ }^{74}$

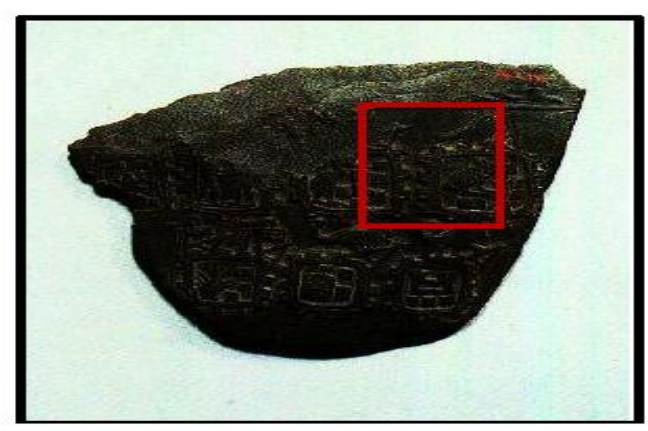

Fig8: An Eared Owl depicted within the walls of one of the Libyan cities, Libyan Palette, discovered in Abydos, First Dynasty, Egyptian Museum (no.14238), Cairo

After: Saleh and Sourouzian 1987, 7, pl.7b

The chieftain of the Owl City is represented wearing the Red Crown of Lower Egypt and some of his titles were recorded on Palermo Stone. Newberry assumed that this city is Sais. Before the unification of Narmer, the ruler of Sais was called Neithhotep meaning "Neith is satisfied". This name is written with the palace façade, a shield, and two crossed arrows suggesting apparently its authority over the TeHenu territories. However, no other archaeological evidence mentions the existence of this Owl City. ${ }^{75}$ Pettigrew described the owl as the sacred bird of Sais. ${ }^{76}$

The description of Sais being "the Owl City" is a topic of interest. Its main deity was Neith who was identified by the Greeks with Athena. ${ }^{77}$ Several historians like Diodorus Siculus, believed that the Athenians were originally colonists from Sais. ${ }^{78}$ In his Critias which is dated to 395 B.C., Plato described the struggle between ancient Athens and the fictional island of Atlantis. The struggle ends with the sink of Atlantis into the Atlantic Ocean due to the divine punishment to the island. ${ }^{79}$ It was believed that this story was based on the visit of the Greek legislator Solon to Egypt in 590 B.C. Plutarch stated that Solon visited the temple of Neith at Sais. The priests of the temple told Solon a considerable account on the island of Atlantis. ${ }^{80}$ Solon assumed that there was a connection between the demolition of the main colony in Greece and the divine punishment of Atlantis which occurred because of its excessive aggression against Egypt as well as Greece. ${ }^{81}$

The Greek community appeared in Egypt even before the arrival of Alexander the Great in 332 BC $^{82}$ as early as the $26^{\text {th }}$ dynasty. ${ }^{83}$ They settled in Egyptian Delta particularly Neukratis ${ }^{84}$. According to Herodotus, the Greek city of Athens was built by a colony from city of Sais ${ }^{85}$ Herodotus stated that the Athenians paid a special attention to the Egyptian city of Sais where its patron goddess Neith, the counterpart of the Greek Athena, was venerated. ${ }^{86}$ The Greek historian threw the light on the annual festival which was celebrated in the honor of Athena in the temple of Neith at Sais. ${ }^{87}$ On the other hand, Plato confirmed in his Timaeus the assimilation between the two goddesses in Sais. ${ }^{88}$

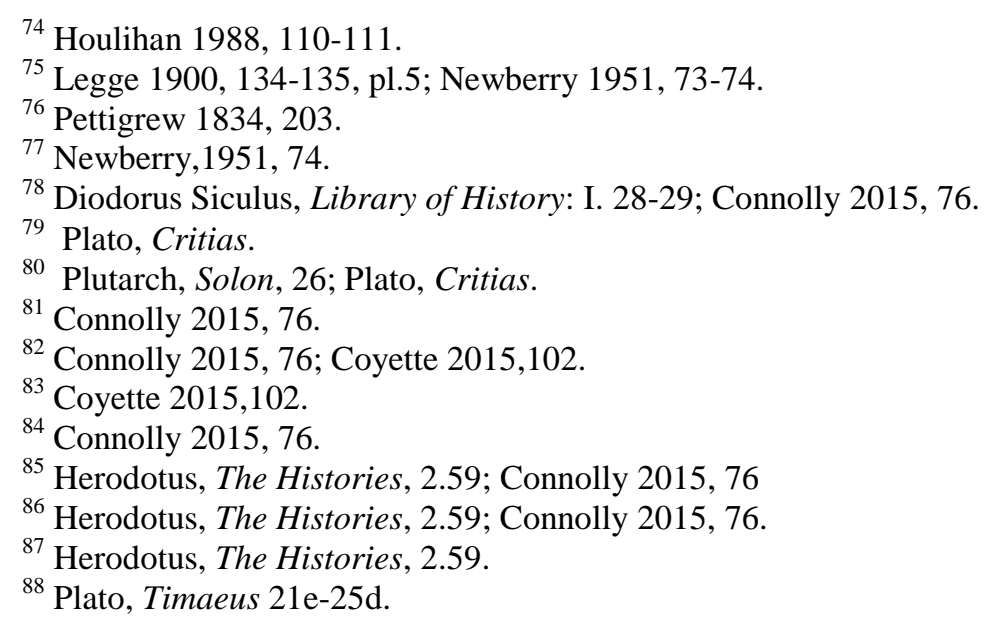


The Little Owl, namely $\Gamma \Lambda \mathrm{AY}^{\prime}$ was called Athene noctua. ${ }^{89}$ The owl $\gamma \lambda \alpha v \dot{\xi}$ was consecrated to goddess Athens as goddess of night and moon. The sacred owl of Athena is always depicted without ears or horns. ${ }^{90}$ The sacred dance of Athens was derived from the name of the owl, namely $\gamma \lambda \alpha \breve{v} \xi$, $\sigma \kappa \omega \dot{ } \psi^{91}$ and $\sigma \kappa \omega \pi i \alpha \varsigma^{92}$

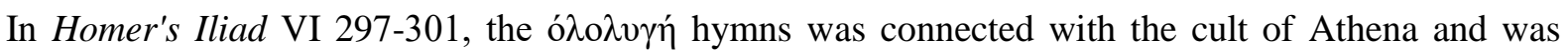
regarded an imitation of the owl, the Roman ulula. ${ }^{93}$ In Homer, the title of Athena was $\gamma \lambda \alpha v \kappa \omega ́ \pi \mathrm{s}$ which is interpreted "bright-eyed" a description that might refer to the eyes of her bird, namely the owl. ${ }^{94}$ Among the so-called Corinthian vases, ${ }^{95}$ animal-shaped vases appeared. For instance, there is a Proto-Cornithian perfume bottle is carved in the shape of a colored owl. This remarkable piece dates back to $650-625$ B.C and is now in the Louvre Museum. ${ }^{96}$

The owl became the sacred bird of goddess Athena. ${ }^{97}$ One of the earliest scholars who connected between the owl bird and goddess Athena was Schliemann ${ }^{98}$. He threw the light on the Trojan types of vases known as "owl-vases". The Greek name of these vases, namely $\gamma \lambda \alpha v \kappa \omega ́ \pi \iota \varsigma$, was translated by many scholars to be "owl-faced" eyes". Thus, he related between this name and goddess Athena who was the goddess of flashing eyes; a relation that was attested by the end of the seventh century B.C ${ }^{100}$. The reason behind this relation was apparently due to Athena who was described to have remarkable eyes. Some regarded the small owl of Athena, namely $\gamma \lambda \alpha v \dot{\xi}$ an abbreviated form of the word $\gamma \lambda \alpha v \kappa \omega ́ \pi \mathrm{s} \varsigma{ }^{101}$. Other scholars rather believe that the owl was related to Athena because of the large number of owls found in the city ${ }^{102}$. A third group of scholars believe that the relation between Athena and the owl is because of the

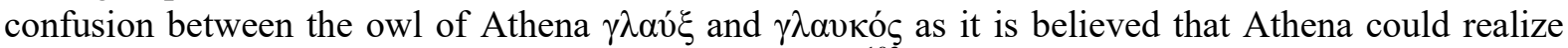
the problems like the owl who could see in the darkness. ${ }^{103}$

In Greek art, the figure of the owl was sometimes found in the scenes of Athena's birth. ${ }^{104}$ In Greek art the owl even replaced the shape of goddess Athena herself. For instance, there is an amphora which dates back to the 550 B.C. and preserved in the Archaeological Seminar in Upsala. It depicts a youth presenting a bull as a sacrifice to an owl perching on an altar in front of him. Moreover, Corinthian pinax ${ }^{105}$ depicts the shape of an owl standing upon an oven. This iconography might refer

${ }^{89}$ Keller 1913, 39; Thompson 1936, 45; Meillier 1970, 9; Coyette 2015, 102.

${ }^{90}$ Keller 1913, 39-40; Thompson 1936, 46 Newberry 1951, 74; However, the kantharos in the National Museum of Copnehagen represents an Eared Owl of Athens; Nilsson 1927, 423; Newberry 1951, 74.

91 Thompson 1936, 46; Lawler 1939, 484.

${ }^{92}$ Lawler 1939, 484. This dance was described by Pollux, Aelian, and Athenaeus to be performed by a single male dancer who imitated the dance of the owl and was encircled by group of owl catchers who try to catch the sacred bird imitator. The whole performance included waddling, shaking the head up and down and moving the neck in fast strange movements. On the other hand, the dance of Athena might refer to the movement of the owl itself. For further detail see; Lawler 1939, 482-502.

${ }^{93}$ Thompson 1936, 53; Meillier 1970, 6; Herodotus thinks that these hymns appeared for the first time in Libya; Herodotus, Persian Wars IV, 189, Newberry 1951, 74.

${ }^{94}$ Douglas 1912, 176; Meillier 1970, 6; Morford and Lenardon 2003, 128,167, 465, 579.

95 This type of Corinthian vases is two handled vases cups (skyphoi), jugs as well as perfume pots; Richter 1992, 303.

${ }^{96}$ Meillier 1970, pl. I b; Richter 1992, 303, fig. 419.

${ }^{97}$ Keller 1913, 39; Edmond 1924, 28-30; Newberry 1951, 74; Coeuret 1976, 197; Roman and Roman $2010,91$.

${ }^{98}$ Schliemann 1880, 217, 225, 247, 281-283; 286-291; 329-344; Imhoof-Blumer and Keller 1889, Taf. v, 16; Farnell 1896, i.261-321; Thompson 1936, 79; Lawler 1939, 493; 45; Douglas 1912, 176.

${ }^{99}$ Nilsson 1927, 421-424; 292; Lawler 1939, 493.

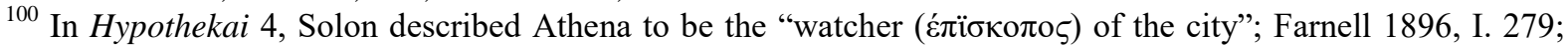

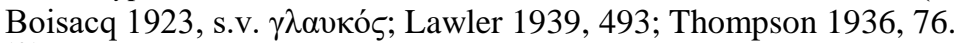

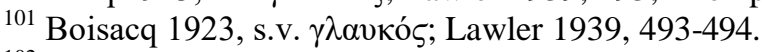

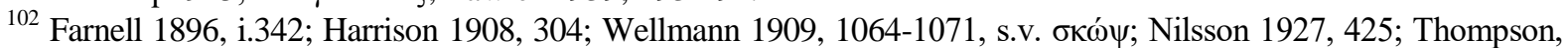
1936, 79; Lawler 1939, 493-494.

${ }^{103}$ Pottier 1908, 545; Lawler 1939, 494; Meillier 1970, 6-7.

${ }^{104}$ Jahn 1854, no. 645; Douglas 1912, 176-177; Edmond 1924, 28-30; Coeuret 1976, 197; For example, there is a vase preserved now among the collection of München (no. 645). It depicts the scene of Athena's birth. God Zeus is represented seated on a lion headed seat. He is accompanied with Eileithyia making her magic, Ares as an armed man, and Apollo Citharoedus playing with his eight- stringed lyre. Hermes is depicted wearing his winged Petasos. Athena is painted springing up from the head of her father while her sacred bird is depicted standing on his wrist; Jahn 1854 , no. 645; Douglas 1912, 176-177, fig.1.

${ }^{105}$ Pinax is a type of potter presented as votive offerings during the seventh century B.C.; Douglas 1912, 177 
to the role of goddess Athena as a divine patron of pottery in Greece. The goddess is depicted standing in front of a kiln on a vase preserved now in Berlin Museum in order to ward off all the evil demons. ${ }^{106}$

Both goddess Neith and Athena were patron deities of weaving and spinning. ${ }^{107}$ Athena was depicted in the form of the owl, her sacred bird, spinning wool from a basket in front of her ${ }^{108}$. Loom-weights were sometimes decorated with the shape of the owl referring to goddess Athena. ${ }^{109}$ Her Egyptian counterpart Neith was mainly connected with the mummification bandages and its necessary ointment. Thus, she became gradually connected with weaving. ${ }^{110}$ The association between Athena and Neith as a weaving goddess is attested as early as the Old Kingdom. ${ }^{111}$ The main sacred emblems of goddess Neith were the crossed arrows, often placed on a shield and the weaver's shutter. ${ }^{112}$

During the Græco-Roman period, Neith was described in a text in Esna temple to be "mistress of the oil of unction as well as the pieces of cloth". ${ }^{113} \mathrm{Her}$ main cult center Sais was described to be the "mansion of weaving". ${ }^{114}$ An important Theban manuscript describes the Embalming Ritual and dates back to the late first century AD or the beginning of the second century AD. This manuscript is called P. Boulaq III ${ }^{115}$ which throws the light on Sais as the manufacture center of mummy bandages which were woven by Neith. Hymns were recited by the dead to goddess Neith to protect the bandages of his mummy which were made by her in Sais. ${ }^{116}$

In Greek myth, goddess Athena was goddess of wisdom and war ${ }^{117}$; the same function which Neith played in the Egyptian mythology. ${ }^{118}$ Neith was described to be "mistress of the bow' and 'ruler of the arrows". ${ }^{119}$

${ }^{106}$ Douglas 1912, 174-178.

${ }^{107}$ Rovik 2002, 86, 91; Jordan 2004, 37; Wilkinson 2005, 157; Roman and Roman 2010, 92; Athena was basically the Greek goddess of all sorts of handicrafts including; pottery, goldsmith, and spinning and weaving. Many historical sources described the role of Aethan as goddess of weaving. For instance, in Homer's Odessey 7.110-111, the skillful female weaver Phaiakian was described to "dowered with wisdom bestowed by Athene, to be expert in beautiful work". In Iliad 14.178-79, Athena weaved an elaborate robe for goddess Hera. In Iliad 5.735, she weaved for herself a richly decorated dress. Furthermore, in Hesiod's Works and Days, Athena weaved for Pandora a beautiful veil and robe. She even taught Pandora "to weave a complex warp". The Ovid's Metamorphoses described a weaving competition between Athena and the maiden Arachne. Because of Archane's swagger, Athena cursed the maiden and transformed her to a spider to weave for the rest of her life. In the festival of Athena, one of the main celebrations is named the Panathenaia. It includes presenting a new robe to the main statue of the goddess. This woven peplos was elaborated with scenes of the mythological battle between the gods and the Titans; Ovid Metamorphoses 6.5; Lattimore 1967, 114; Meillier 1970, 620; Barber 1992, 105-106; Milanezi 2001, 323, n. 63; Ackerman 2008, 4-7, 13, 14 fig.8,9.

${ }^{108}$ Barber 1992, 106; Ackerman 2008, 7.

109 These small objects were apparently used as votive offerings and measured $60-70 \mathrm{~mm}$ in length. The first side was kept without decoration. The second side bears the shape of the owl; the face is turned en face to the viewer while the body is executed in profile. Two human arms appear from the body of the owl and holds the wool to spine it. The wool comes from a kalathos placed on the ground. Another examples of these loomweights show goddess Athena as a woman headed owl; Douglas 1912, 177-178, fig. 3; Ackerman 2008, 8, fig.3

110 Bleeker 1967, 42, 54; El-Saady 1994, 216; Rovik 2002, 86; Wilkinson 2005, 157; Ackerman 2008, 4; The role of Neith as a protectress of the mummy bandages is emphasized during the Græco-Roman era when Neith became more connected with Isis, Nephthys, the weaving goddess Tayet and with eye of Horus; El-Saady 1994, 216, note 48; El-Sayed 1982 II, 491, Doc.704, 500, Doc.718, 584, Doc.932, 572, Doc. 908d.

${ }^{111}$ El-Sayed 1982 I, 17-18.

${ }^{112}$ Rovik 2002, 86.

${ }^{113}$ Hollis 1997, 212; Ackerman 2008, 4.

${ }^{114}$ El-Sayed 1975, 180; El-Saady 1994, 216.

${ }^{115}$ Champan 2016, 4, 51: This papyrus belongs to Hatres who was a Theban priest for the cult of Amun Re and other divinities; Smith 2017, 503.

${ }^{116}$ El-Sayed 1982 I, 77-79: 1982 II: 333; El-Saady 1994, 216.

${ }^{117}$ Roman and Roman 2010,91; According to a small pottery piece which is now preserved in Petri collection, Athena was described with the following words; "Upon her head she placed the helmet with two horns and with four bosses, forged of gold... Then she stepped upon the flaming chariot and grasped her spear, heavy and huge and strong, with which she smites the legions of men". This description was a small part of the poem of Homer's Illiad which throws the light on the Trojan war. For further detail see; Connolly 2015, 76.

${ }^{118}$ Rovik 2002, 86; Hart, 2005, 100; Wilkinson 2005, 157.

${ }^{119}$ In Egyptian myth, Neith appeared to be one of the personifications of the Eye of Re. In the Contending of Horus and Seth which dates back to the Ramesside period, Neith was the advisor of the sun god Re. Erman 1903, 13; Hart 2005, 100; Wilkinson 2005, 157. 
Being two symbols of goddess Athena, ${ }^{120}$ the shape of the owl was depicted standing upon an olive branch on the earliest coins of Athens. ${ }^{121}$ The invention of the Athenain owl coin is due to the Greek stateman Pisistratus. This leader seized the Athenian Acropolis in 561 B.C. and announced himself as the master of the city. A few years later, Pisistratus erected the festival of the city' s goddess Athena and issued the coin of the city. This coin bore the shape of Athena, her sacred bird and the Greek letters $\mathrm{E} \Theta \mathrm{A}$ to send an obvious message to the world that this coin is "of the Athenians". The coin was issued as a silver tetra drachma ${ }^{122}$.

It is worth to note the iconography of the owl standing upon an olive branch on the Athenian coins. This association might refer to the primitive function of Athena as a goddess of fertility. ${ }^{123}$ The shape of the owl is also accompanied with olive trees on the Libyan palette. Together with the TeHenu lands, olive trees were depicted on the reverse of this palette. ${ }^{124}$ Both the owl and the olive branch are two elements inspired from the Libyan landscape and consecrated for goddess Athena. ${ }^{125}$ Thus, this iconography might reflect the cult of goddess Athena associated with goddess Neith in the Libyan region. The cult of Neith-Athena was introduced to the Pre-Hellenic Greek pantheon in North Africa by the middle of the third millennium B.C. By the $6^{\text {th }}$ century B.C., Athena appeared in her Hellenistic fusion with the Corinthian helmet and Libyan aegis on the Corinthian vases. Contemporary to this period, the Egyptian Neith appeared in the sun temple of Userkaf of the fifth Dynasty and then in Sais wearing the Red Crown. ${ }^{126}$ This hypothesis confirms that the so-called Owl City on the Libyan palette is definitely Sais, the main cult center of Neith-Athena. In other words, the owl was the sacred bird of Neith-Athena in the Pre-Hellenic world before the characters of Neith and Athena as two independent goddesses were identified.

After the triumph of King Mina in Fayum, which is commemorated on his palette, Libyans began to settle in Lower Egypt. Their capital Sais became the cult center for their goddess Neith. ${ }^{27}$ Greek and Roman coins from Sais are decorated with the shape of goddess Athena and later with her Roman counterpart Minerva ${ }^{128}$ and identified with the Egyptian goddess Neith. ${ }^{129}$ According to the monuments of the twenty-six dynasty (Saite Period) in Sais, Neith was the patron goddess of the nome and was entitled "mistress of Sais". Her worship was apparently carried from Egypt to Athens ${ }^{130}$.

It could be noticed that the shape of the owl became an important motive in the Egyptian monetary system in Egypt. The iconography of this bird on coinage system is based on being the sacred bird of Athena as a goddess of war. This might explain its appearance on the coins during the Persian

${ }^{120}$ Jordan 2004, 37; Roman and Roman 2010, 91.

${ }^{121}$ Keller 1913, 39-40; Thompson 1950, 151-154; Newberry 1951, 74; Hipólito 1998, 150-151, nr.142; Roman and Roman 2010, 91.

${ }^{122}$ Seltman 1942, 42-47; Thompson 1950, 151-152, fig.1; Starr 1970, 10-12: The Galouste Gulbenkian Museum preserves two ancient Greek golden coins of the owl accompanied with Athena. The first one dates back to 87/86 B.C. The obverse of this coin represents the head of Athena in profile. She wears a triple-crested Attic helmet decorated with the shape of the Pegasus. On the reverse the owl is depicted in profile to the right. Its head is carved en face and his wings are closed. He is depicted perching on an amphora. On the left and right

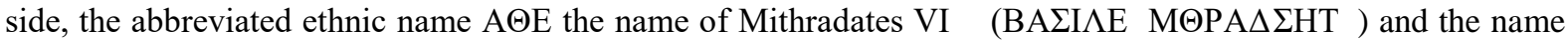

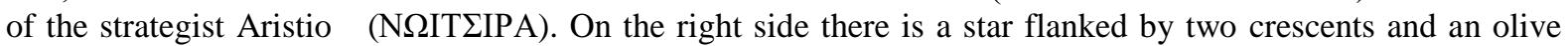
wreath border. The second one dates back to 296 B.C. The obverse depicts the same goddess wearing her Attic helmet decorated with olive leaves. The reverse represents the owl in profile with his head en face with closed

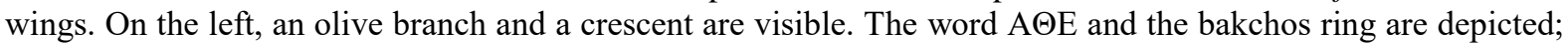
Hipólito 1998, 150-151, nr.115, 142. For further examples see; Seltman 1942, 168-217: Starr 1970.

${ }^{123}$ Meillier 1970, 6; Morford and Lenardon 2003, 167.

${ }^{124}$ Legge 1900, 134-135, pl.5; Newberry 1951, 73-74; Saleh and Sourouzian 1987, 7, pl.7a,7b; Houlihan 1988, $110-111$.

${ }^{125}$ Erman 1903, 13; Rovik 2002, 85-89; Jordan 2004, 37; The olive tree was sacred to goddess Athena. It was found on the Acropolis hill and its oil was presented to the victories during the Panatheaia festival; Jordan $2004,37$.

${ }^{126}$ Erman 1903, 13; Rovik 2002, 85-89; Jordan 2004, 216-217; Neith was sometimes called Neith of Libya; a title that might refer to her Libyan origin; Wilkinson 2005, 157-158.

${ }^{127}$ In order to legitimize his rule, Mena is said to marry a Saite princess called Neithhotep, meaning Neith is satisfied; Mackenzie 1912, 34, 171.

${ }_{128}$ Roman and Roman 2010, 90.

${ }^{129}$ Birch 1838-1842, 104; Newberry 1951, 74; Wiedemann 1971, 258-263; Hart 2005, 100.

${ }^{130}$ Mackenzie 1912, 171; Rovik 2002, 85-89; the Athenians regarded the owl to be the symbol of sciences. This concept was not found by the Egyptians; Birch 1838-1842, 104 
invasion in Egypt and during the Ptolemaic Period, the Fourth Egyptian-Syrian War in particular. The so-called Athenian coins began to appear in Egypt as early as the fifth century B.C. By the end of the same century, Egyptian issues of these coins became more prominent in Egypt. ${ }^{131}$ Thus, the owl became a prominent figure of the silver Athenian coins that spread widely by the fourth and fifth century B.C. in the monetary coinage system of Egypt. Hoards of coins were discovered in various places in Delta including Neucratis. ${ }^{132}$ Hoard of owl coins were also discovered in Assiut in Upper Egypt. ${ }^{133}$

Among the depicted Athenian coins of Neucratis, there is an interesting example. This piece was discovered in Sakha, $3 \mathrm{~km}$ south of Kafr El Sheik. This small village was known as Xios, the ancient metropolis of the Sixth Nome of Lower Egypt. The piece is a small coin made of pure silver and suggested according to its weight to be a Tritemorion. ${ }^{134}$ The bird on the reverse is similar to the hieroglyphic sign of the owl than the owl of Athens which is remarked by its big rounded eyes and short tail. ${ }^{135}$ The depicted owl here is near to reality and is apparently the Barn Owl. ${ }^{136}$ The Athenian inspiration is recognized through the Greek inscription $\mathrm{A} \Theta \mathrm{E}$, on the right of the head of the bird. However, this silver piece is clearly Egyptian and marked with the Egyptian sign of silver ${ }^{\circ}$ (fig. 9). ${ }^{137}$

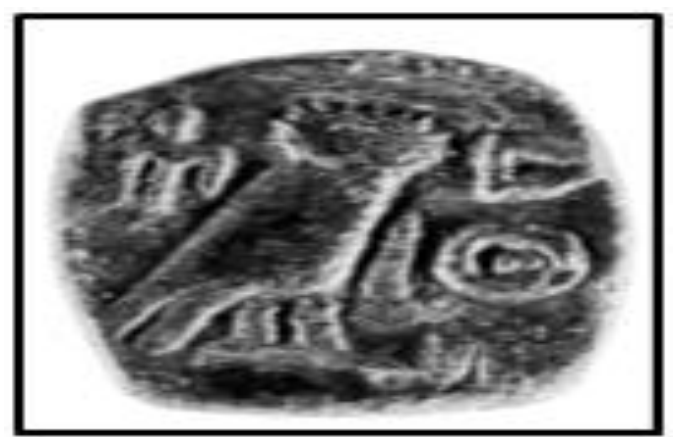

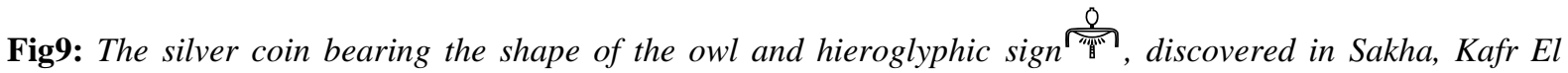
Sheif, Delta

After: Goyon 1987, Pl.43

According to Seltman, the Athenian coins discovered in Neucratis belong to Class L which dates back to the period between 506 B.C. and 490 B.C. On this type of coins, the figure of the owl takes more the triangular shape accompanied with the olive twig. ${ }^{138}$ Other part of the Athenian Coins in Neucratis were categorized as Post-Salaminian coins that were issued before the reign of Salamis between 490 B.C. and 480 B.C. On these coins, the owl appeared as a rounded bird but smaller in size. ${ }^{139}$

It was thought that the owl coins of Neucratis became a substitute of the original Athenian ones. This theory was led by Newell who discovered the first type of coins there. ${ }^{140}$ However, it is rather believed that these bronze coins were followed ethnic bronze ones bearing the legend NAU instead of the Athenian ethnic $\mathrm{A} \Theta \mathrm{E} \cdot{ }^{141}$ According to Le Rider, coins of Neucratis date back as early as Kleomenes, the financial administrator of Egypt during the reign of Alexander in 332-331 B.C. ${ }^{142}$

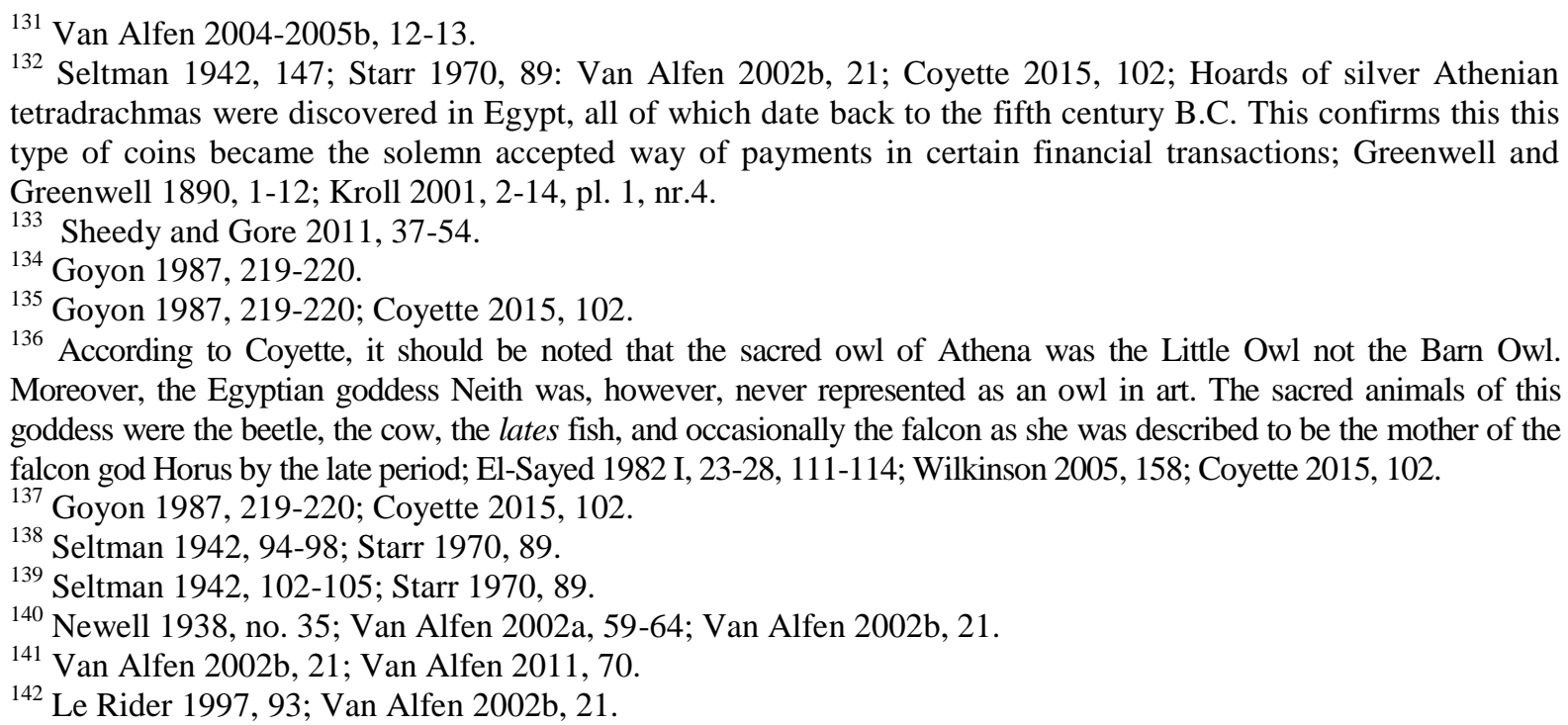
tetradrachmas were discovered in Egypt, all of which date back to the fifth century B.C. This confirms this this type of coins became the solemn accepted way of payments in certain financial transactions; Greenwell and Greenwell 1890, 1-12; Kroll 2001, 2-14, pl. 1, nr.4.

133 Sheedy and Gore 2011, 37-54.

${ }^{134}$ Goyon 1987, 219-220.

135 Goyon 1987, 219-220; Coyette 2015, 102.

136 According to Coyette, it should be noted that the sacred owl of Athena was the Little Owl not the Barn Owl. Moreover, the Egyptian goddess Neith was, however, never represented as an owl in art. The sacred animals of this goddess were the beetle, the cow, the lates fish, and occasionally the falcon as she was described to be the mother of the falcon god Horus by the late period; El-Sayed 1982 I, 23-28, 111-114; Wilkinson 2005, 158; Coyette 2015, 102.

${ }^{137}$ Goyon 1987, 219-220; Coyette 2015, 102.

${ }^{138}$ Seltman 1942, 94-98; Starr 1970, 89.

${ }^{139}$ Seltman 1942, 102-105; Starr 1970, 89.

${ }^{140}$ Newell 1938, no. 35; Van Alfen 2002a, 59-64; Van Alfen 2002b, 21.

${ }^{141}$ Van Alfen 2002b, 21; Van Alfen 2011, 70.

${ }^{142}$ Le Rider 1997, 93; Van Alfen 2002b, 21. 
This opinion was argued by V. Alfen and Bresson since the imitation of the Athenian coins occurred in Egypt as early as the fourth century B.C. Thus, the previous date could not be confirmed. ${ }^{143}$

Based on the hoard discoveries, Egypt was the most remarkable places for imitating Athenian coins during the classical period. This imitation took place as early as the fifth century B.C. till the reign of Alexander the Great. Thus, it could be said the monetary system in Egypt before the arrival of Alexander the Great based mainly on imitative owl coins. ${ }^{144}$ Buttery who studied discovered hoard of Athenian owls in Fayoum believes that this type of coins was minted by Egyptian under a governmental supervision in Memphis. These coins spread widely and reached as far as the Aegean Sea. ${ }^{145}$

Petrie published a coin that was discovered in Egypt and now preserved in the Petrie Museum of Archaeology. It depicts the bust of Athena wearing her crested helmet. On the other side, the figure of the owl was depicted. According to Petrie, this coin was a fake one that was used either presented as a votive offering to the goddess or functioned as theater tickets (fig.10). ${ }^{146}$

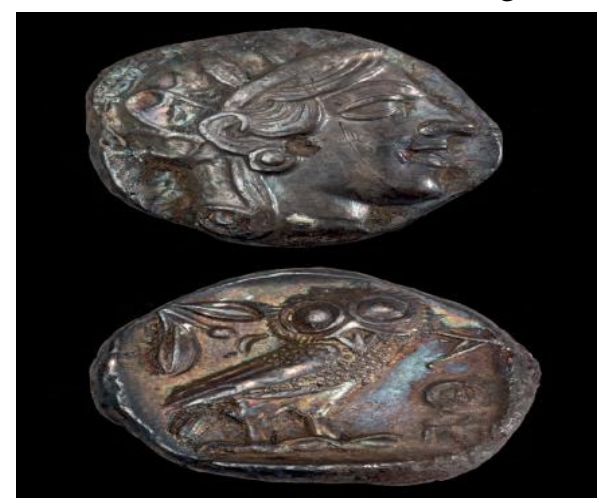

Fig10: Bronze coin discovered by Petrie. It depicts the bust of Athena wearing her crested helmet (reverse) and the shape of the owl (obverse), Petrie Museum of Egyptian Archaeology, UC39201

After: Connolly 2015, 77

Furthermore, a silver Athenean tetradrachma was discovered in Egypt and now are preserved by the American Numismatic Society. The coin dates back to the fifth century B.C. and depicts on its obverse the head of goddess Athena. She is depicted with frontal eyes and wearing a helmet decorated

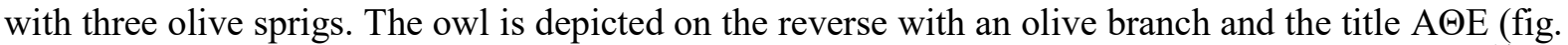
11). Despite of the bad state of the coin, Kroll dates it to the third quarter of the fifth century B.C. ${ }^{147}$

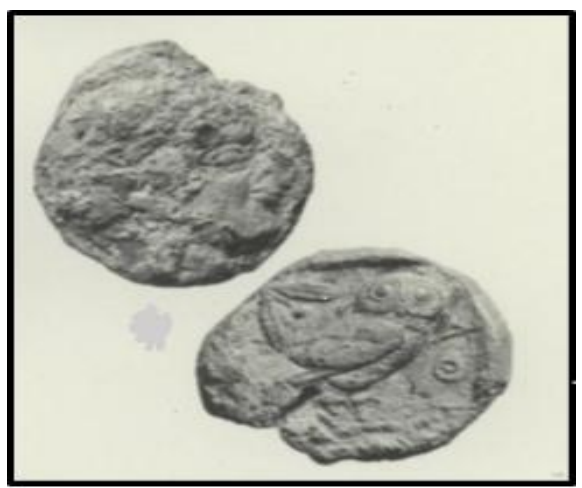

Fig11: silver tetradrachma depicting the head of goddess Athena (obverse) and the owl with an olive branch (reserve), discovered in Egypt and now are preserved by the American Numismatic Society (IGCH 1647), fifth century B.C.

After: Kroll 2001, plate 1, fig.4

${ }_{143}^{143}$ Bresson 2000, 75; Van Alfen 2002b, 21; Van Alfen 2011, 66-70.

${ }^{144}$ Van Alfen 2011, 70.

${ }^{145}$ Van Alfen 2011, 67-70; Buttery threw the light on the hoar of owl-coins discovered in Fayoum and categorized them according to their signature into various categories, see; Buttrey 1982, 137-140; Buttrey 1984, 292-294.

${ }^{146}$ Connolly 2015, 76.

${ }^{147}$ Kroll 2001, 2-14, pl. 1, nr.4; IGCH 1647.

International Journal of History and Cultural Studies (IJHCS) 
In Tel El-Maskhuta, more than 6000 of Athenian coins were discovered bearing the sacred bird of Athena, namely the owl. ${ }^{148}$ These coins date back to the second half of the fifth century B.C. Among the coins, thirteen silver tetradrachmas are now preserved in the Nicholson Museum at Sydney University. The obverse bears the head of goddess Athena crowned with a diadem. As for the reverse,

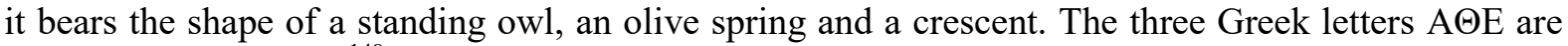
also engraved (fig.12). ${ }^{149}$

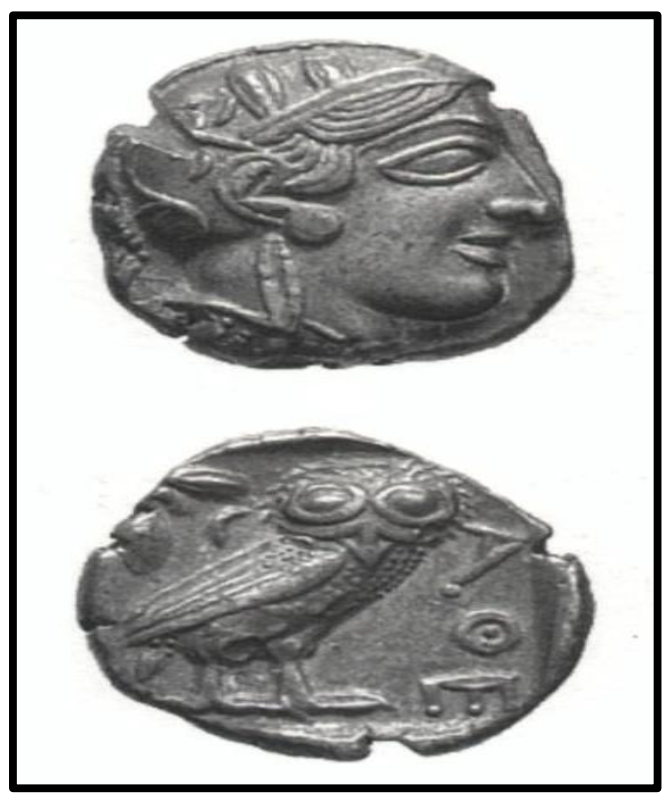

Fig12: Silver tetradrachma depicting the head of Athena (obverse), standing owl (reverse), discovered in Tall el-Maskhouta, second half of the fifth century B.C., preserved in the Nicholson Museum at Sydney University NM 2003.250/2

After: Hardwick 2006, pl.74, nr. 2.

The owl, as the sacred bird of the war goddess Athena, appeared in coins in Egypt during the Persian period. It became a prominent figure decorating the so-called "Sabakes-type" coins in Egypt that date back to the second half of the fourth century B.C. This type of coins was apparently issued by the Persian administration during that time to commemorate Sabakes, the Persian satrap of Egypt. These coins reveal many remarkable details of the owl (fig.13). ${ }^{150}$

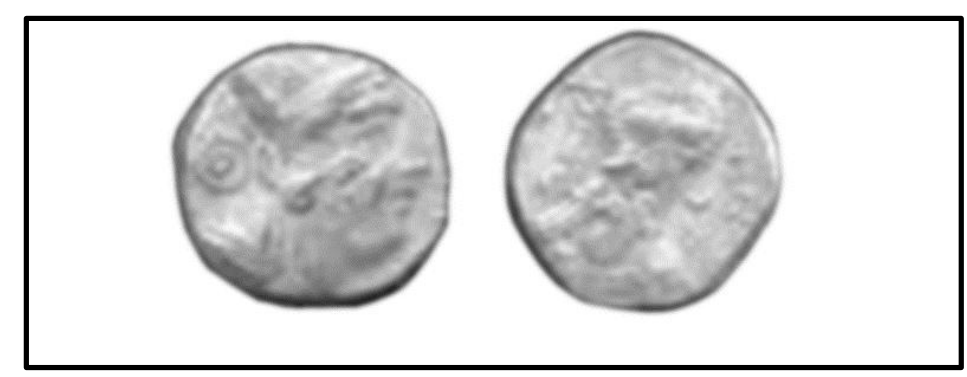

Fig13: Sabakes Coin bearing the shape of the Persian Satrap of Egypt (obverse) and the shape of the Owl (reverse)

After: Van Alfen 2004- 2005a, pl 10, nr 51

The shape of the owl appeared on the so-called Serapis and Isis silver tetradrachmas. This type of coins is one of the remarkable coins issued in Egypt during the Ptolemaic era in the period between the reign of Ptolemy IV Philopator and Ptolemy V. Thus, Serapis and Isis coins began to be issued by

${ }^{148}$ Thompson 1950, 153-154, fig.4; Van Alfen 2002a, 64-65; Hardwick 2006, 382-384, pl.74.

${ }^{149}$ Hardwick 2006, 382-384, pl.74. Similar coins were published by Van Alfen and preserved now among the collection of the American Numismatic Society. The ten Athenian coins date back to 460 B.C. For further details, see; Van Alfen 2002a, 64-65; Van Alfen 2004-2005b, 7-46.

150 Thompson 1950, 153-154; Van Alfen 2002b, 15-16; Van Alfen 2004-2005a, 47-61; 
the Fourth Syrian War. The obverse of these coins depicted the busts of Serapis and Isis in profile directed to the right. Serpais is represented wearing the Atef crown and Isis wears the Hathouric crown. On the reverse, the eagle is depicted with the thunderbolt, the cornucopia, as well as the royal diadem. The two Greek words ПTO $\Lambda$ EMAIOY (left) and BA $\Sigma \mathrm{I} \Lambda \mathrm{E} \Omega \Sigma$ (right) are engraved along the border of the reverse. In some examples, a small shape of an owl is depicted on the right side of the eagle. The two Greek letters MO are engraved on the left of the eagle and the two letters AP (fig.14a) or ON (fig.14b) are on the right beneath the shape of an owl. ${ }^{151}$

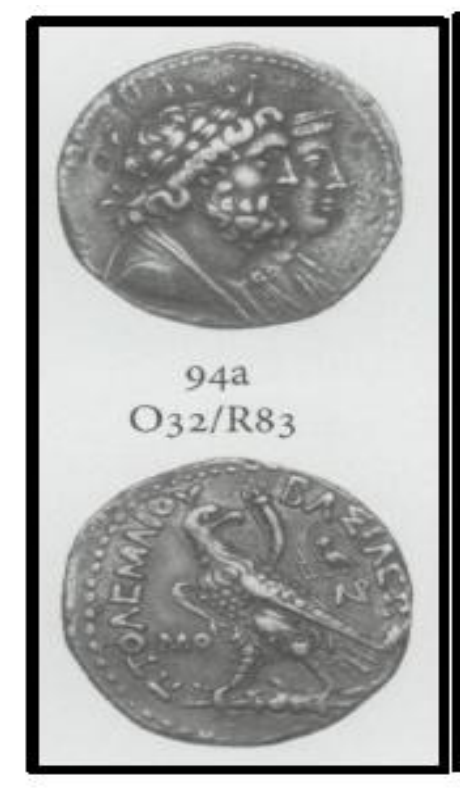

A

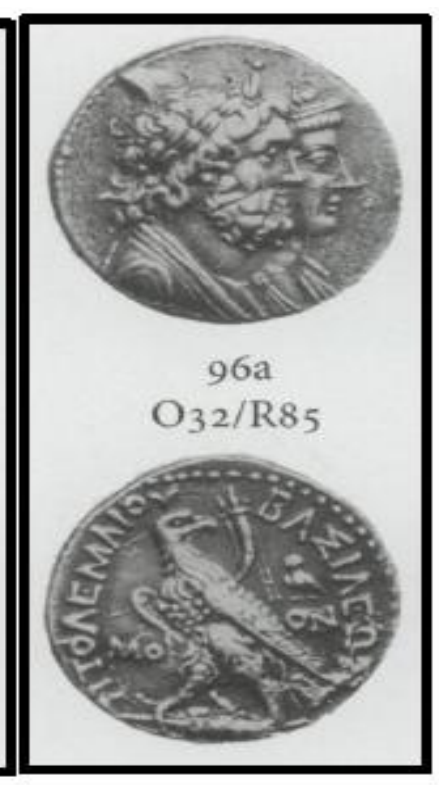

B

Fig14a,b: Silver tetradrachma revealing the bust of Serapis and Isis (reverse) and the eagle (obverse), the small shape of an owl is engraved over the two Greek letters AP (fig.8a) and ON (fig. 8b), Ptolemaic period, reign of Ptolemy IV Philopator

After: Landvatter 2012, 61-63, 74-75, pl.19, O32/R83; O32/R85

\section{REFERENCES}

[1] Ackerman, S. 2008. "Asherah, the West Semitic Goddess of Spinning and Weaving." JNES 67 no. 1: 1-30.

[2] Arnold, D. 1995. "An Egyptian Bestiary." BMMA V, 52, no. 4.

[3] Barber, E. J. W. 1992. "The Peplos of Athena,." In Goddess and Polis: The Panathenaic Festival in Ancient Athens, edited by J. Neils: 104-105. Hanover: New Hampshire and Princeton.

[4] Bleeker, C. J. 1967. "The Goddess Neith." In Studies in Mysticism and Religion Presented to Gershom G. Scholem on His Seventieth Birthday by Pupils, Colleagues, and Friends, edited by E. E. Urback, R. J. Z. Werblowsky, and Ch. Wirszubski, 42-54. Jerusalem: Hebrew University.

[5] Boisacq, E. 1923. Dictionnaire etymologique de la langue grecque. Heidelberg and Paris: C. Klincksieck.

[6] Birch, S. 1838-1842. "Researches Relative to the connection of the Deities represented upon the Coins of Egyptian Nomes with the Egyptian Pantheon.” The Numismatic Chronicle 2: 86-107.

[7] Bresson, A. 2000. La cité merchande, Bordeaux: de Boccard.

[8] Brugsch, H. 1868. Über Bildung und Entwicklung der Schrift bei Virchow-Holtzendorf, Sammlung gemeinwissenschaftlicher Vorträge, Series III, nr. 64. Berlin: C. G. Lüderitzsche Verlagsbuchhandlung.

[9] Buttrey, T.V. 1982. "Pharaonic Imitations of Athenian Tetradrachms." In Proceedings of the $9^{\text {th }}$ International Congress of Numismatics, Berne, September 1979, vol. I, edited by T. Hackens, and R. Weiller, 137-140. Louvain-la-Neuve \& Luxembourg: Association Internationale des Numismates Professionnels.

${ }^{151}$ Landvatter 2012, 61-63, 74-75, pl.19, O32/R83; O32/R84;O32/R85; Being contemporary to the Egyptian Syrian War, similar issues of the Ptolemaic coins of Serapis and Isis appeared on the coins of the Seleucid king Antiochus III from Soli. This might indicate the existence of the Ptolemaic mint officials in Soli which was captured by the Seleucids in 197 B.C. Lorber and Kovacs believe that this type of Seleucid coins appeared during the reign of Ptolemy V (205-280 B.C.) who lost his authority in Cilicia during the Fifth Syrian War against Antioch III. For further detail, see; Landvatter 2012, 81. 
[10] Buttrey T. V. 1984. "Seldom What They Seem: the Case of the Athenian Tetradrachm." In Ancient Coins of the Græco-Roman World: the Nickle Numismatics Papers, edited by W. Heckel, and R. Sullivan, 292294. Waterloo: Wilifrid Laurier University Press for the Calgary Institute for the Humanities.

[11] Champan, S. L., 2016. The Embalming Ritual of Late Period through Ptolemaic Egypt. PhD Thesis. University of Birmingham: College of Art and Law. http://etheses.bham.ac.uk/7771/1/Chapman17PhD.pdf

[12] Coeuret, G. 1976. "La chouette de Thésée-la-Romaine." Revue archéologique du Centre de la France, tome 15, fascicule 3-4: 195-197.

[13] Connolly, E. 2015. "She smites the legions of men': a Greek goddess in Egypt." In The Petrie Museum of Egyptian Archaeology: Characters and Collections, edited by A. Stevenson, 76-77. London: UCL Press.

[14] Cory, A. T. 1840. The Hieroglyphics of Horapollo Nilous. London: William Pickering.

[15] Cottevieille-Giraudet, R. 1931. Rapport sur les Fouilles de Médamoud. Le Caire: FIFAO 9.

[16] Coyette, A. 2015. "Hiboux et chouettes pharaoniques." In Apprivoiser le sauvage, edited by M. Massiera, B. Mathieu, and Fr. Rouffet, Cahiers-Égypte Nilotique et Méditerranéenne 11: 93-104. Montpellier: Université Paul Valéry Montpellier.

[17] De Montfaucon, B. 1722. L'antiquité expliquée et représentée en figures, Tome Second, Seconde Partie; La Religion des Egyptiens, des Arabes, des Syriens, des Perfes, des Scythes, des Germains, des Gaulios, des Espagnols \&des Cathaginois. Paris: F. Delaulne, $2^{\text {nd }}$ ed. https://gallica.bnf.fr/ark:/12148/ bpt6k114618 r.texteImage

[18] Diodorus Siculus, translated by C.H. Oldfather, C. L. Sherman, C. B. Welles, R. M. Geer, and, F. Walton, 1933. Library of History Book I. Loeb Classical Library. London: William Heinemann: 28-29 http:// penelope.uchicago.edu/Thayer/E/Roman/Texts/Diodorus_Siculus/1A*.html

[19] Douglas, E. M. 1912. "The Owl of Athena.” JHS 32: 174-178.

[20] D' Lortet, L., and M. C. Gaillard, 1905. La Faune momifiee de l'ancienne I. Lyons: Henri Georg, Éditeur.

[21] Edmond, P. 1924. "La chouette d'Athéné.” BAssBudé 2: 27-30.

[22] El-Saady, H. 1994. "Reflections on the Goddess Tayet." JEA 80: 213-217.

[23] El-Sayed, R. 1975. Documents relatifs a Sais et ses divinites. Bibliothèque d'étude 69. Le Caire: institut français d'archéologie orientale.

[24] El-Sayed, R. 1982. La deesse Neith de Sais (2. Vol.). Bibliothèque d'étude 86. Le Caire: Institut français d'archéologie Orientale.

[25] Erman, A. 1903. A Handbook of Egyptian Religion. London: Archibald Constable \& Co.LTD.

[26] Erman, A., and Grapow, H. 1971. Wörterbuch der Aegyptishen Sprache, Band I, II und III. Berlin: Akademie Verlag.

[27] Farnell, L. R. 1896. The Cults of the Greek States. Oxford: Clarendon Press.

[28] Gardiner, A. 1927. Egyptian Grammar: Being an Introduction to the Study of Hieroglyphics. Oxford: Clarendon Press, 1st ed.

[29] Gardiner, A. 1950. Egyptian Grammar: Being an Introduction to the Study of Hieroglyphics. Griffith Institute, Ashmolean Museum, Oxford: Oxford University Press, $2^{\text {nd }}$ ed.

[30] Gautier, A. 1987. "Taphonomic Groups: How and Why?” Archaeozoologia 1 no. 2: 47-52.

[31] Goyon, G. 1987. “La plus ancienne (?) monnaie frappée en Égypte : un tritemorion. ” BIFAO 87: $219-223$.

[32] Greenwell, W., and C. Greenwell. 1890. "On a Find of Archaic Greek Coins in Egypt.” The Numismatic Chronicle and Journal of the Numismatic Society 10, Third Series: 1-12.

[33] Hardwick, N. 2006. "IGCH 1649: Tell El Maskhouta (anc. Pithom-Hermopolis), 17 km W. of Ismailia, 1947-1948." NC 166: 382-384.

[34] Hart, G. 2005. The Routledge Dictionary of Egyptian Gods and Goddesses. London and New York: Routledge, $2^{\text {nd }}$ ed.

[35] Herodotus, The Histories, 2.59. http://perseus.uchicago.edu/perseus-cgi/citequery3.pl?dbname= GreekFeb $2011 \&$ getid=1\&query=Hdt. $\% 202.59 .2$

[36] Herodotus, Translated by A. D. Godley. 1920. Persian Wars IV. Loeb Classical Library. Cambridge: Harvard University Press. 1920. http://www.perseus.tufts.edu/hopper/text?doc=Perseus:text: 1999.01.01 26: book=4: chapter $=189$

[37] Hipólito, M. C., 1998. Ancient Greek Coins; Gold. Translated by M. Ayton. Lisbon: The Calouste Gubenkian Museum.

[38] Hollis, S. T. 1997. "Queens and Goddesses in Ancient Egypt.” In Women and Goddess Traditions: In Antiquity and Today, Studies in Antiquity and Christianity, edited by K. L. King, with an introduction by K. J. Torjeson, 210-238. Minneapolis, M.N: Fortress Press. 
[39] Harrison, J. E. 1908. Prolegomena to the Study of Greek Religion. Cambridge: Cambridge University Press.

[40] Houlihan, P. F. 1996. The Animal World of the Pharaohs. Cairo: American University.

[41] Houlihan, P. F. 1988. The Birds of Ancient Egypt. Cairo: American University Press.

[42] Ikram, S. 2004. Beloved Beasts: Animal Mummies from Ancient Egypt. Cairo: The Supreme Council of Antiquities.

[43] Imhoof-Blumer, F., and O. Keller. 1889. Tier- und Pflanzenbilder auf Münzen und Gemmen des klassischen Altertums. Leipzig: Teubner.

[44] Jahn, O. 1854. Beschreibung der Vasensammlung Konig Ludwigs in der Pinakothek zu München. Leipzig: Druck von Giesecke \& Devrient.

[45] Jordan, M. 2004. Dictionary of Gods and Goddesses. New York: Facts on File, $2^{\text {nd }}$ ed.

[46] Kaplony, P. 1966. Kleine Beiträge Zu Den Inschriften Der Ägyptischen Frühzeit. Ägyptologische Abhandlungen 15. Wiesbaden: Otto Harrassowitz.

[47] Kaplony, P. 1977. "Eule.” LÄ II. Wiesbaden: Otto Harrassowitz: 39-40.

[48] Keel, O. 1977. Vögel als Boten: Studien zu Ps 68, 12-14, Gen 8, 6-12, Koh 10,20 und dem Aussenden von Botenvögeln in Ägypten. Freiburg, Switzerland/ Göttingen, Germany: Universitätsverlag / Vandenhoeck Ruprecht.

[49] Keller, O. 1913. Die Antike Tierwelt Zweiter Band: Vögel, Reptilien, Fische, Insekten, Spinnentiere, Tausendfüssler, Krebstiere, Würmer, Weichtiere, Stachelhäuter, Schlauchtiere. Leipzig: Verlag von Wilheim Engelmann.

[50] Kemp, A.C., 1988. "Strigidae, Typical Owls." In The Birds of Africa III, edited by C.H. Fry, S. Keith, and E.K Urban, 110-155. London: Academic Press.

[51] Kessler D. and A. Nur el-Din. 2005. "Tuna al-Gebel: Millions of Ibises and Other Animals," In Divine Creatures: Animal Mummies in Ancient Egypt, edited by S. Ikram, 120-163. Cairo: American University Press.

[52] Kroll, J. H. 2001. “A Small Find of Silver Bullion in Egypt.” AJN 13:1-20.

[53] Landvatter, T. 2012. "The Serapis and Isis Coinage of Ptolemy IV." AJN 24: 61-90.

[54] Lattimore, R. 1967. The Odyssey of Homer. New York: Harper\& Row.

[55] Lawler, L. B. 1939. "The Dance of the Owl and Its Significance in the History of Greek Religion and the Drama." TAPA 70: 482-502.

[56] Legge, F. 1900. "The Carved Slates from Hieraconopolis and Elsewhere." Proceedings of the Society of Biblical Archaeology 22: 125-139.

[57] Le Rider, G. 1997. "Cléomène de Neucratis.” BCH 121: 71-93.

[58] Linseele, V., Van Neer, W., and R. Friedman, 2009. "Special Animals from a Special Place? The Fauna from HK29A at Predynastic Hierakonpolis." JARCE 45: 105-136.

[59] Mackenzie, D.A. 1912. Egyptian Myth and Legend. Alexandria: Library of Alexandria.

[60] Malaise, M. 1993. "Le faucon et la chouette d'Harpocrate." In Individu, société et spiritualité dans l'Égypte pharaonique et copte. Mélanges égyptologiques offerts au Professeur Aristide Théodoridès, edited by Chr. Cannuyer, and et J.-M. Kruchten: 147-154. Ath-Bruxelles, Mons: Assostiona Montoise d'Égyptologie.

[61] Meek, D. 1977. “Harpokrates.” Lexikon der Ägyptologie II. Wiesbaden: Otto Harrassowitz: 1003-1011.

[62] Meinertzhagen, C. R. 1930. Nicoll's Birds of Egypt II. London: H. Rees Ltd.

[63] Meillier, C. 1970. "La chouette et Athéna." RÉA 72, n. 1-2: 5-30.

[64] Milanezi, S. 2001. "Headaches and Gnawed Peplos: Laughing with Athena." In Athena in the Classical World, edited by S. Deacy and A. Willing, 310-329. Leiden: E.J. Brill.

[65] Morford, M.P.O., and R. J. Lenardon 2003. Classical Mythology. New York, Oxford: Oxford University Press, $7^{\text {th }}$ edition.

[66] Newberry, P. E. 1951. "The Owls in Ancient Egypt," JEA 37: 72-74.

[67] Newell, E. T. 1938. Miscellanea numismatica: Cyrene to India. NNM 82. New York: American Numismatic Society.

[68] Nilsson, M. P. 1927. The Minoan-Mycenaean Religion and Its Survival in Greek Religion. London: Oxford University Press.

[69] Ovidius Naso, Metamorphoses Book V. Translated by I. Johnston, 533-371. http://www.latinandgreek.Org /_files/live/LCCS_Latin_on_the_Lawn_2012_Metamorphoses_332-571_English.pdf 
[70] Ovid, Translated by M. Brookes. 1922. Metamorphoses. Boston, Cornhill Publishing Co: 6.5 http://www.perseus.tufts.edu/hopper/text?doc=Ov.+Met.+6.5\&fromdoc=Perseus\%3Atext\%3A1999.02.00 28

[71] Pettigrew, T. J. 1834. A History of Egyptian Mummies: and an Account of the Worship and Embalming of the Sacred Animals. London: Longman, Rees, Orme, Brown, Green, and Longman, Paternoster Row.

[72] Pottier, E. 1908. "La chouette d' Athene," BCH 32: 529-548.

[73] Plato, Translated by W.R.M. Lamb. 1925. Timaeus. London, William Heinemann Ltd: 21e-25d. http://www.perseus.tufts.edu/hopper/text?doc=Perseus\%3Atext\%3A1999.01.0180\%3Atext\%3DTim.\%3A section\%3D21e Plato, Critias. http://classics.mit.edu/Plato/critias.html

[74] Plutarch, Translated by B. Perrin. 1914. Solon. London. William Heinemann Ltd: 26 http://www.perseus.tufts. edu / hopper/text?doc=Plut.+Sol.+26\&fromdoc=Perseus\%3Atext\%3A2008.01.0063

[75] Richter, G. M. A. 1992. A Handbook to Greek Art; A Survey of the Visual Arts of Ancient Greece. London: Phaidon Press, $9^{\text {th }}$ ed.

[76] Roman, L., and M. Roman, 2010. Encyclopedia of Greek and Roman Mythology. New York: Facts on File.

[77] Rovik, P. W. 2002. “A Libyan Athena with Ancient Greek Inscriptions,” MeditArch 15: 81-94.

[78] Saleh, M., and H. Sourouzian. 1987. The Official Catalogue: The Egyptian Museum Cairo. Mainz: Verlag von Philipp von Zabern.

[79] Schliemann, H. 1880. Ilios: City and Country of the Trojans. New York: Harper and Bros.

[80] Seltman, C 1942. Athens: Its History and Coinage before the Persian Invasion. Cambridge: Ares Publishers INC.

[81] Sheedy, K. A., and D. B. Gore 2011. "Asyut 422, Seltman Group P, and the Imitation of Attic Coins." Belgisch Tijdschrift voor Numismatiek en Zegelkunde 157. Bruxelles: Brussel: 37-54.

[82] Smith, M., 2017. Following Osiris: Perspectives on the Osirian Afterlife from the Four Millenia. Oxford: Oxford University Press.

[83] Starr, C. G. 1970. Athenian Coinage 480-449 B.C. New York: Numismatic Publication.

[84] Stricker, B.H. 1957. "De heilige uil." Oudheidkundige Mededelingen vit het Rijksmuseum van Oudheden 37. Leiden.

[85] The Official Web Site of the Bibliothèque nationale de France (BnF) (inv.52.6557) http://medaillesetantiques. bnf.fr/ws/catalogue/app/collection/record/ark:/12148/c33gbfppk?fbclid=IwAR3sF8qUymWJkQmuXbmBujB_N5NaXw79AZ2nlyc_G5OkVplC8PV7Is4nB4

[86] The Official Web Site of the Metropolitan Museum of Art_(Accession Number: 26.7.1082) https://images. metmuseum.org/CRDImages/eg/original/26.7.1082_front.nk.jpg

[87] Thompson, D. W. 1936. Glossary of Greek Birds. London: Humphrey Milford.

[88] Thompson, M. 1950. "The 'Owls' of Athens.” Archaeology 3, no. 3: 151-154.

[89] Van Alfen, P. G. 2002a. "Two Unpublished Hoards and Other Owls from Egypt.” AJN 14: 59-71.

[90] Van Alfen, P. G. 2002b. "The "Owls" from the 1989 Syria Hoard, with a Review of Pre-Macedonian Coinage in Egypt." AJN 14: 1-57.

[91] Van Alfen, P. G. 2004- 2005a. "A New Athenian "Owl” and Bullion Hoard from the Near East." AJN Second Series 16/17: 47-61.

[92] Van Alfen, P. G. 2004-2005b. "Herodotus' "Aryandic" Silver and Bullion Use in Persian-Period Egypt." AJN 16/17:7-46.

[93] Van Alfen, P. G. 2011. "Mechanisms for the Imitation of Athenian Coinage: Dekeleia and Mercenaries Reconsidered." Belgisch Tijdschrift voor Numismatiek en Zegelkunde 157. Bruxelles: Brussel: 55-93.

[94] Vernus, P. 2005. “Chouette, hibou." In Le Bestiaire de Pharaons, edited by P. Venus, and Y. Yoyotte, 361. Paris: Editions Perrin.

[95] Von Den Driesch, A., D. Kessler, F. Steinmann, V. Berteauxand, and J. Peters 2005. "Mummified, Deified and Buried at Heermopolis Magna-The Sacred Birds from Tuna El-Gebel, Middle Egypt." Ägypten und Levante 15. Vienna: Austrian Academy of Sciences Press: 203-244. http://www.jstor.org/stable/23788261

[96] Wellmann, M. 1909. "Eule.” In Paulys Realencyclopädie der classischen Altertumswissenschaft VI, edited by G. Wissowa, 1064-1071. Stuttgart: Metzler.

[97] Wiedemann, A. 1971. Herodots Zweites Buch: Mit Sachlichen Erläuterungen. Milano: CisalpinoGoliardica.

[98] Wilkinson, R. 2005. The Complete Gods and Goddesses of Ancient Egypt. Cairo: American University Press. 


\section{AUTHOR'S BIOGRAPHY}

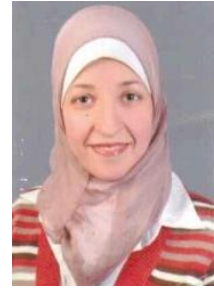

Dr. Sara El Sayed Kitat, Associate Professor of Egyptian Archaeology and Civilization during the Greek, Roman, and Byzantine Period. Faculty of Tourism and Hotels, Alexandria University, Egypt. Master in Tourism, Hotels, and Tourist Guiding in 2006. The thesis is titled \&quot;Gods of Medicine in Ancient Egypt (Cultural and Tourist Study)\&quot;. PhD in Tourism, Hotels, and Tourist Guiding in 2010. The thesis is titled: \&quot;Water Divinities in Egypt during the Græco- Roman Period (A religious archaeological, and Tourist Study)\&quot;.

Citation: Sara El-Sayed Kitat. "The Veneration of the Owl in Graco-Roman Egypt". International Journal of History and Cultural Studies (IJHCS). vol 5, no. 2, 2019, pp. 1-20. doi: DOI: http://dx.doi.org/ 10.20431/2454-7654.0502001.

Copyright: (C) 2019 Authors. This is an open-access article distributed under the terms of the Creative Commons Attribution License, which permits unrestricted use, distribution, and reproduction in any medium, provided the original author and source are credited. 